\title{
Changes in bird communities of Admiralty Bay, King George Island (West Antarctic): insights from monitoring data (1977-1996)
}

\author{
Kazimierz SIERAKOWSKI ${ }^{1}$, Małgorzata KORCZAK-ABSHIRE ${ }^{1 *}$ \\ and Piotr JADWISZCZAK ${ }^{2}$ \\ ${ }^{1}$ Institute of Biochemistry and Biophysics, Polish Academy of Sciences, \\ Pawińskiego 5a, 02-106 Warsaw, Poland \\ 2 Department of Genetics and Evolution, Institute of Biology, University of Bialystok, \\ K. Ciołkowskiego 1J, 15-245 Bialystok, Poland \\ * corresponding author<mka@ibb.waw.pl>
}

\begin{abstract}
The paper summarizes results of twenty years of seabird observations carried out between 1977 and 1996 on the western shore of Admiralty Bay (King George Island, South Shetlands, Antarctic). Changes in population size, distribution and phenology of the breeding species as well as the appearance of non-breeding species are reported. A total of 34 species of birds were observed, including 13 breeding species. Among the non-breeding species, four were observed to visit the site regularly, six rarely, and the remaining 11 were observed only occasionally. Among breeding populations, three Pygoscelis penguin species, the main krill consumers, were most numerous. The Adélie Penguin ( $P$. adeliae) dominated among the penguins nesting in the investigated areas, reaching 23,661 breeding pairs in 1978. Two other penguin species were less abundant with population sizes of approximately 7,200 breeding pairs for the Chinstrap Penguin (P. antarcticus) and 3,100 breeding pairs for the Gentoo Penguin (P. papua) in the same year. During the following two decades, breeding populations of pygoscelid species experienced a declining trend and their numbers were reduced by $68.0 \%$ for Chinstrap, $67.1 \%$ for Gentoo, and $33.9 \%$ for Adélie Penguins. The data reported here represent a unique reference basis and provide valuable information about indicator species, suitable for comparison with contemporary observations of bird populations in the Antarctic Peninsula region, a place of rapidly occurring climate changes and intensive harvesting of marine living resources.
\end{abstract}

Key words: Antarctic, Admiralty Bay, ASPA 128, volant birds, penguins, census. 


\section{Introduction}

Data from long-term bird population surveys, both census and auxiliary notes, constitute a valuable source of information for conservation and scientific purposes (e.g. Lynch et al. 2012). They are especially important for the regions experiencing environmental change or increasing human impact, or both - like the region of Antarctic Peninsula. Such studies have revealed widespread fluctuations in population size and phenology in wildlife due to changing climate, in both the Northern (Menzel et al. 2006; Sydeman and Bogard 2009; Körner and Basler 2010; Gilg et al. 2012) and Southern Hemispheres (Hindell et al. 2012; Chambers et al. 2013; Black 2016). However, regional differences in climate change and biotic characteristics as well as climate-induced impacts on particular species may differ in their nature and magnitude between regions and ecosystems.

King George Island (Fig. 1), the largest of the South Shetland Islands, is characterized by its abundant and divergent avifauna (e.g. Myrcha 1993). The first phenological observations of birds in Admiralty Bay area were carried out in 1977 (Trivelpiece and Volkman 1979; Presler 1980). Studies of penguin populations were continued in subsequent years by Jabłoński (1984a, 1984b, 1986, 1987), Trivelpiece et al. (1987b, 1990, 2011), Ciaputa and Sierakowski (1999), and Hinke et al. (2007). The earliest census of the whole avifauna of the Admiralty Bay area (the largest bay of King George Island) was reported by Jabłoński (1986) and since 1988 a regular monitoring of birds on the western shore of Admiralty Bay has been carried out (Sierakowski 1991; Lesiński 1993; Jabłoński 1995).

Here we report on a long-term survey of the breeding and non-breeding birds of the Admiralty Bay using data collected in 1977-1996 time frame. Our study covers the time period corresponding to the first twenty years of scientific activity at the Arctowski Station, which is a good point of reference for further research, and ultimately - better understanding the more recent changes in the bird populations of this area.

\section{Research area and methods}

Research area. - King George Island (Fig. 1), is the largest $\left(1150 \mathrm{~km}^{2}\right)$ of the South Shetland Islands, located at the northern tip of the Antarctic Peninsula, separated from it by the Bransfield Strait. Less than $10 \%$ of the island is icefree area. It is one of the most densely inhabited (by humans) regions of the Antarctic with numerous year-round research stations and a smaller number of summer-only posts. Admiralty Bay $\left(62^{\circ} 01{ }^{\prime} 21^{\prime \prime} \mathrm{S}, 58^{\circ} 15^{\prime} 05^{\prime \prime} \mathrm{W}\right.$; Fig. 1) is protected as an Antarctic Specially Managed Area (ASMA 1), including an Antarctic Specially Protected Area (ASPA 128, until 2002 known as the Site of 


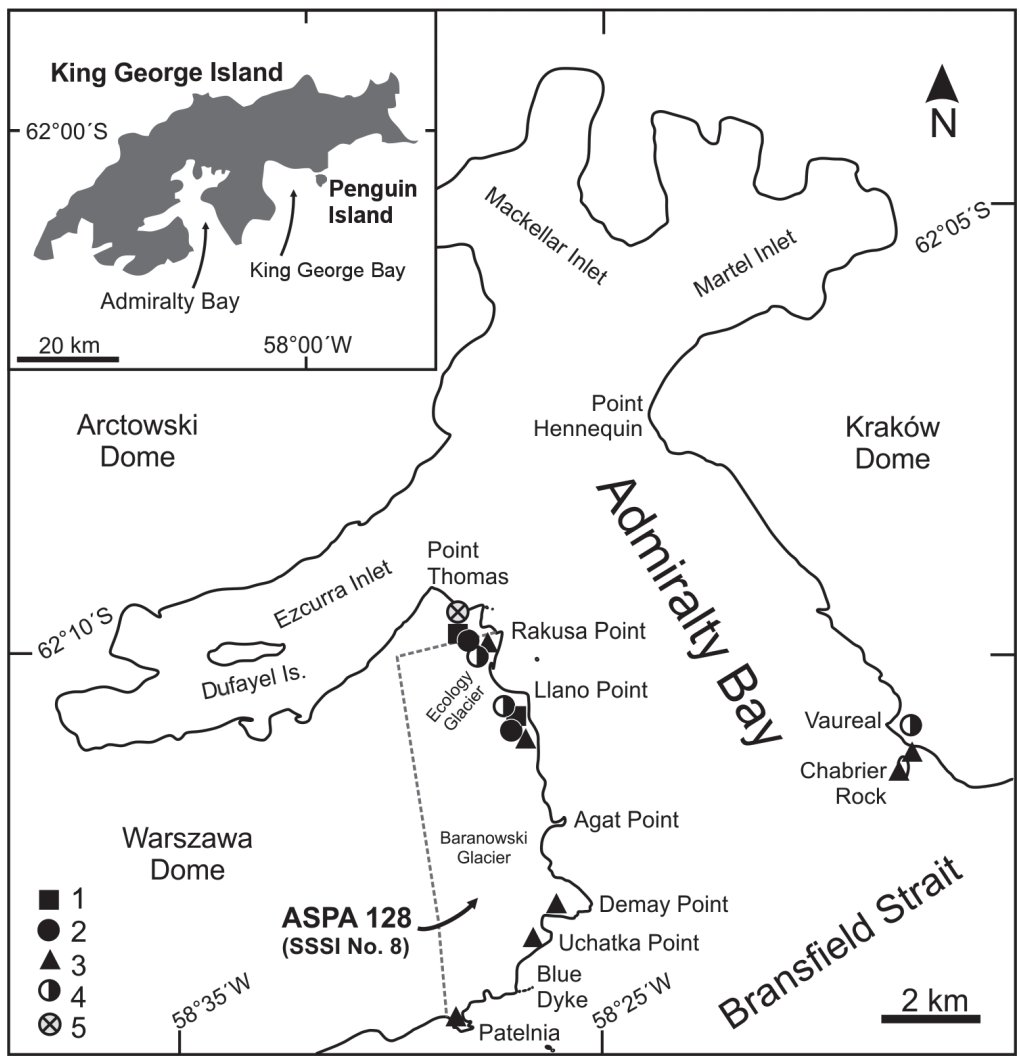

Fig. 1. Map of Admiralty Bay with marked seabird colonies (1-4). Key to symbols: 1 (square) Pygoscelis papua, 2 - (circle) Pygoscelis adeliae, 3 (triangle) - Pygoscelis antarcticus, 4 (black and white circle) - Macronectes giganteus, 5 - Arctowski Station.

the Special Scientific Interest [SSSI] No. 8; Fig. 2), which encompasses much of its western shore (see the Antarctic Treaty database, Measure 2 [2006] - ATCM XXIX - CEP IX, Edinburgh, http://www.ats.aq/devAS/info_measures_listitem. aspx?lang=e\&id=358). In 1977, the Arctowski Polish Antarctic Station was established at Point Thomas in Admiralty Bay, and it has remained the main facility for continuous scientific research in the immediate vicinity of SSSI No. 8.

The climatic conditions of King George Island depend mainly on the sea temperature and sea-ice extent in the area of the nearby Antarctic Peninsula (Kejna et al. 2013 and references therein). A characteristic feature on the island is the large variability in thermal conditions from year to year (Kejna 1999 and references therein). The Admiralty Bay area has pronounced fluctuations regarding the season beginning and end dates which is related to changes in the atmospheric circulation. The longest season is the winter, which lasts an average of 135 days, and its duration varies from 96 to 195 days. The shortest 
season is summer, which lasts an average of 52 days, and its duration varies between 31 and 96 days (Kejna 1992).

The ornithological research was carried out within the ice-free area of the western shore of Admiralty Bay and mainly focused on the SSSI 8 area (c. $17.3 \mathrm{~km}^{2}$ ) (Figs 1-2). The observations started in 1977 and lasted to the end of 1996. During this time, there has been rapid deglaciation events which has resulted in the ice-free area increasing nearly threefold (Fig. 2; Pudełko 2002). The observed trends in changeability of ice conditions and air temperature during the period covered by our investigations were not statistically significant (Kruszewski 2002).

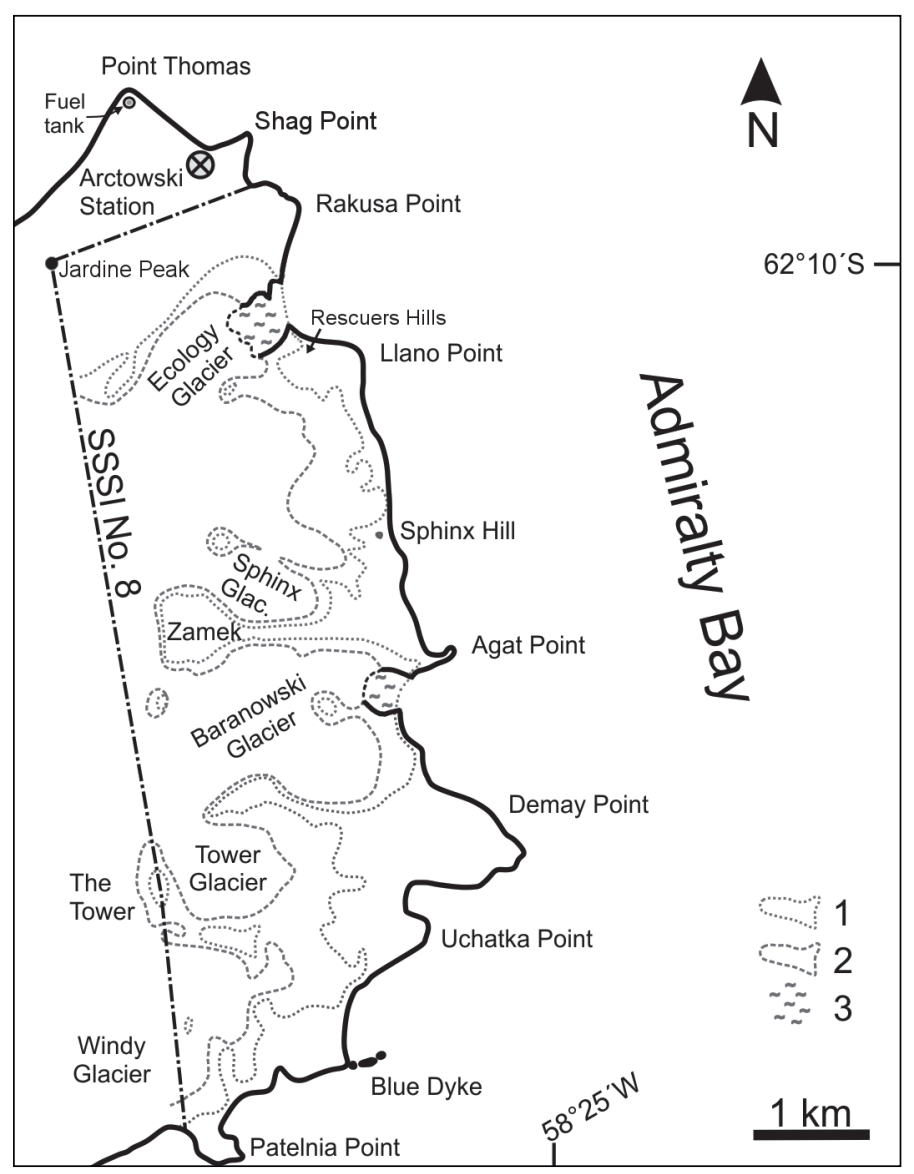

Fig. 2. Changes of glaciers topography in SSSI No. 8. Key to symbols: 1 - permanent ice cover range in 1979, 2 - permanent ice cover range in 1999, 3 - lagoon formed 1999. The presented map was created according to Battke and Cisak (1988) [Cape Lions Rump, 1:5 000 scale. Institute of Ecology, Polish Academy of Sciences, Warsaw] as well as Pudełko R. (2002) [Site of Special Scientific Interest No. 8 (SSSI-8), King George Island, 1:12 500, IUNG Puławy]. 
Birds census. - For penguins species (Table 1), three different quantitative estimation methods were used depending on the topography, size and spatial arrangement of breeding colonies.

1) Small breeding groups not exceeding 100 nests, and up to 300 nests in the case of long and narrow aggregations. Each year approximately one week after the mean date of clutch initiation, the number of occupied nests were counted. Three separate counts were done on the same day. If one of the three counts differed more than $10 \%$ from the others, a fourth was made. If the results differed no more then by $10 \%$, the mean value was calculated (for all three species).

2) Middle size breeding groups, more than 300 nests. If the topography allowed, images of numerous breeding groups were taken from elevations (for all three penguin species). The counts of nest numbers were done from the enlarged photographs taken according to breeding phenology, see method 1 .

3) Large Adélie Penguin breeding colonies (>1000 nests). Estimations were based on counting nests within one hundred sample plots $16 \mathrm{~m}^{2}$ each and extrapolating the results to the known area of the entire colony.

Table 1

List of breeding and non-breeding birds observed in the Admiralty Bay area (King George Island) between 1977 and 1996. Status of non-breeding - visiting: regularly - species observed almost every year; rarely - species observed in 3 to 6 different seasons; occasionally - species (mostly one individual) recorded once or twice during the study period.

\begin{tabular}{|c|c|c|c|c|}
\hline \multirow{3}{*}{ Species } & \multicolumn{4}{|c|}{ Status } \\
\hline & \multirow{2}{*}{ breeding } & \multicolumn{3}{|c|}{ non-breeding - visiting } \\
\hline & & regularly & rarely & occasionally \\
\hline $\begin{array}{l}\text { King Penguin } \\
\text { Aptenodytes patagonicus (Miller, 1778) }\end{array}$ & & & & $X$ \\
\hline $\begin{array}{l}\text { Emperor Penguin } \\
\text { Aptenodytes forsteri (Gray, 1844) }\end{array}$ & & & & $\mathrm{X}$ \\
\hline $\begin{array}{l}\text { Gentoo Penguin } \\
\text { Pygoscelis papua (Forster, 1781) }\end{array}$ & $\mathrm{X}$ & & & \\
\hline $\begin{array}{l}\text { Adélie Penguin } \\
\text { Pygoscelis adeliae (Hombron et Jacquinot, 1841) }\end{array}$ & $\mathrm{X}$ & & & \\
\hline $\begin{array}{l}\text { Chinstrap Penguin } \\
\text { Pygoscelis antarcticus (J.R. Forster, 1781) }\end{array}$ & $\mathrm{X}$ & & & \\
\hline $\begin{array}{l}\text { Southern Rockhopper Penguin } \\
\text { Eudyptes chrysocome (J.R. Forster, 1781) }\end{array}$ & & & $\mathrm{X}$ & \\
\hline $\begin{array}{l}\text { Macaroni Penguin } \\
\text { Eudyptes chrysolophus (Brandt, 1837) }\end{array}$ & & $\mathrm{X}$ & & \\
\hline $\begin{array}{l}\text { Magellanic Penguin } \\
\text { Spheniscus magellanicus (J.R. Forster, 1781) }\end{array}$ & & & & $\mathrm{X}$ \\
\hline $\begin{array}{l}\text { Black-browed Albatross } \\
\text { Thalassarche melanophris (Temminck, 1828) }\end{array}$ & & & $\mathrm{X}$ & \\
\hline
\end{tabular}


Table 1 continued

\begin{tabular}{|c|c|c|c|c|}
\hline \multirow{3}{*}{ Species } & \multicolumn{4}{|c|}{ Status } \\
\hline & \multirow{2}{*}{ breeding } & \multicolumn{3}{|c|}{ non-breeding - visiting } \\
\hline & & regularly & rarely & occasionally \\
\hline $\begin{array}{l}\text { Sooty Albatross } \\
\text { Phoebetria fusca (Hilsenberg, 1822) }\end{array}$ & & & & $X$ \\
\hline $\begin{array}{l}\text { Light-mantled Albatross } \\
\text { Phoebetria palpebrata (J.R. Forster, 1785) }\end{array}$ & & & & $X$ \\
\hline $\begin{array}{l}\text { Southern Giant Petrel } \\
\text { Macronectes giganteus (Gmelin, 1789) }\end{array}$ & $X$ & & & \\
\hline $\begin{array}{l}\text { Southern Fulmar } \\
\text { Fulmarus glacialoides (Smith, 1840) }\end{array}$ & & $X$ & & \\
\hline $\begin{array}{l}\text { Antarctic Petrel } \\
\text { Thalassoica antarctica (Gmelin, 1789) }\end{array}$ & & & $X$ & \\
\hline $\begin{array}{l}\text { Cape Petrel } \\
\text { Daption capense (Linnaeus, 1758) }\end{array}$ & $X$ & & & \\
\hline $\begin{array}{l}\text { Snow Petrel } \\
\text { Pagodroma nivea (G. Forster, 1777) }\end{array}$ & & $X$ & & \\
\hline $\begin{array}{l}\text { Blue Petrel } \\
\text { Halobaena caerulea (Gmelin, 1789) }\end{array}$ & & & & $X$ \\
\hline $\begin{array}{l}\text { Antarctic Prion } \\
\text { Pachyptila vittata (G. Forster, 1777) }\end{array}$ & & & & $X$ \\
\hline $\begin{array}{l}\text { Wilson's Storm Petrel } \\
\text { Oceanites oceanicus (Kuhl, 1820) }\end{array}$ & $X$ & & & \\
\hline $\begin{array}{l}\text { Black-bellied Storm Petrel } \\
\text { Fregetta tropica (Gould, 1844) }\end{array}$ & $X$ & & & \\
\hline $\begin{array}{l}\text { Antarctic Shag } \\
\text { Phalacrocorax atriceps bransfieldensis } \\
\text { Murphy, } 1936\end{array}$ & $X$ & & & \\
\hline $\begin{array}{l}\text { Cattle Egret } \\
\text { Bubulcus ibis (Linnaeus, 1758) }\end{array}$ & & & & $X$ \\
\hline $\begin{array}{l}\text { Black-necked Swan } \\
\text { Cygnus melancoryphus (Molina, 1782) }\end{array}$ & & & $X$ & \\
\hline $\begin{array}{l}\text { Chiloe Wigeon } \\
\text { Anas sibilatrix Poeppig, } 1829\end{array}$ & & & & $X$ \\
\hline $\begin{array}{l}\text { Yellow-billed Pintail } \\
\text { Anas georgica Gmelin, } 1789\end{array}$ & & & $X$ & \\
\hline $\begin{array}{l}\text { White-rumped Sandpiper } \\
\text { Calidris fuscicollis Vieillot, } 1819\end{array}$ & & & $X$ & \\
\hline $\begin{array}{l}\text { Wilson's Phalarope } \\
\text { Phalaropus tricolor Vieillot, } 1819\end{array}$ & & & & $X$ \\
\hline $\begin{array}{l}\text { Pale-faced Sheathbill } \\
\text { Chionis albus Gmelin, } 1789\end{array}$ & $X$ & & & \\
\hline $\begin{array}{l}\text { Chilean Skua } \\
\text { Stercorarius chilensis Bonaparte, } 1857\end{array}$ & & & & $X$ \\
\hline $\begin{array}{l}\text { South Polar Skua } \\
\text { Stercorarius maccormicki Saunders, } 1893\end{array}$ & $X$ & & & \\
\hline
\end{tabular}


Table 1 continued

\begin{tabular}{|l|c|c|c|c|}
\hline \multirow{2}{*}{ Species } & \multicolumn{4}{c|}{ Status } \\
\cline { 2 - 5 } & breeding & \multicolumn{2}{c|}{ non-breeding - visiting } \\
\cline { 3 - 5 } & regularly & rarely & occasionally \\
\hline $\begin{array}{l}\text { Brown Skua } \\
\text { Stercorarius antarcticus lonnbergi Mathews, 1912 }\end{array}$ & $\mathrm{X}$ & & & \\
\hline $\begin{array}{l}\text { Kelp Gull } \\
\text { Larus dominicanus Lichtenstein, 1823 }\end{array}$ & $\mathrm{X}$ & & & \\
\hline $\begin{array}{l}\text { Arctic Tern } \\
\text { Sterna paradisaea } \text { Pontoppidan, 1763 }\end{array}$ & & $\mathrm{X}$ & & \\
\hline $\begin{array}{l}\text { Antarctic Tern } \\
\text { Sterna vittata Gmelin, 1789 }\end{array}$ & $\mathrm{X}$ & & & \\
\hline
\end{tabular}

Nests of breeding pairs of volant bird species were counted directly during the long-term penetration of the area in the particular seasons 1988/89, 1990/91 and in years 1992-1997 (Table 1). The exceptions were the Wilson's Storm Petrel (Oceanites oceanicus) and Black-bellied Storm Petrel (Fregetta tropica), for which only the distribution along the coast was recorded. A unique biology of these two species made it impossible to determine accurate population sizes. The winter surveys after the end of the breeding period within the whole area of Admiralty Bay (including SSSI No. 8) were carried out every ten days. Attention was paid to non-breeding birds visiting the site regularly (almost every year), rarely (observed in 3 to 6 different seasons) and occasionally (recorded once or twice). For population-size changes in all three pygoscelid species, the Mann-Kendall test for trend was performed for the 1978-96 time series, using PAST 3.14 software (Hammer et al. 2001).

The scientific and English common names of birds were based on compilations of the global avifauna (Sibley and Monroe 1990; del Hoyo et al. 1991-1999).

\section{Results}

In total, 34 species of birds were recorded in the Admiralty Bay area between 1977 and 1996, 13 of them were nesting and 21 were classified as non-breeders. Four species from the latter category were observed visiting regularly, six rarely and 11 - occasionally (Table 1 ).

Breeding bird species

Gentoo Penguin (Pygoscelis papua). - There were two breeding colonies of Gentoo Penguins in the Admiralty Bay area. Both were located within the SSSI No. 8, at Point Thomas and Llano Point (Fig. 1). In the breeding season 1978/79, Llano Point colony counted 2,562 P. papua nests (Fig. 4), while the less numerous Point Thomas colony had 783 nests (Fig. 3). The number of 


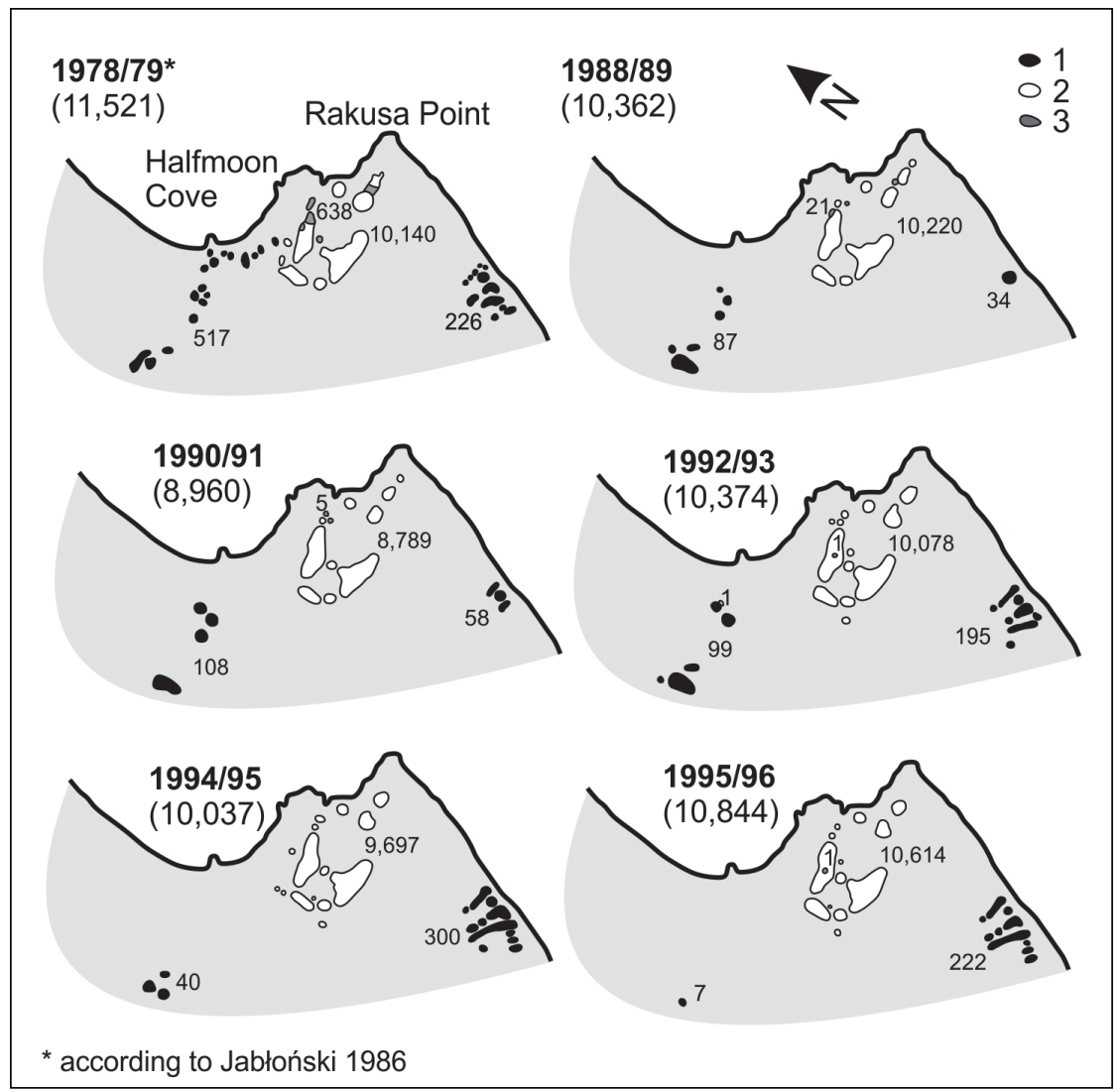

Fig. 3. Distribution of the breeding groups in Point Thomas colony and the number of nests of three species of penguins in particular seasons between 1978 and 1996. Key to symbols: 1 - Pygoscelis papua, 2 - Pygoscelis adeliae, 3 - Pygoscelis antarcticus. Total counts in parentheses.

nests was variable in subsequent years. While population size in Llano Point rookery was quite stable until the season 1992/93 (Fig 4), the Pt. Thomas colony recorded an important decline (Fig. 3). A marked, although statistically insignificant, decrease in the population size has been observed since 1978/79 in the whole SSSI No. 8 (Table 2) ( $\mathrm{n}=12$, Mann-Kendall's $S=-26, Z=1.714$, $P=0.09$ ). Breeding phenology data are presented in Table 3 . After the breeding season, adult individuals remained in the vicinity of their breeding areas to moult. In those winters when the sea around King George Island did not freeze, many individuals (usually more than $25 \%$ of the breeding population) stayed in the Admiralty Bay area. They remained in the sea during the day and in the afternoon they returned to the vicinity of their breeding areas. When the bay got covered by ice, penguins abandoned land, but returned when ice retreated (Sierakowski 1991). 


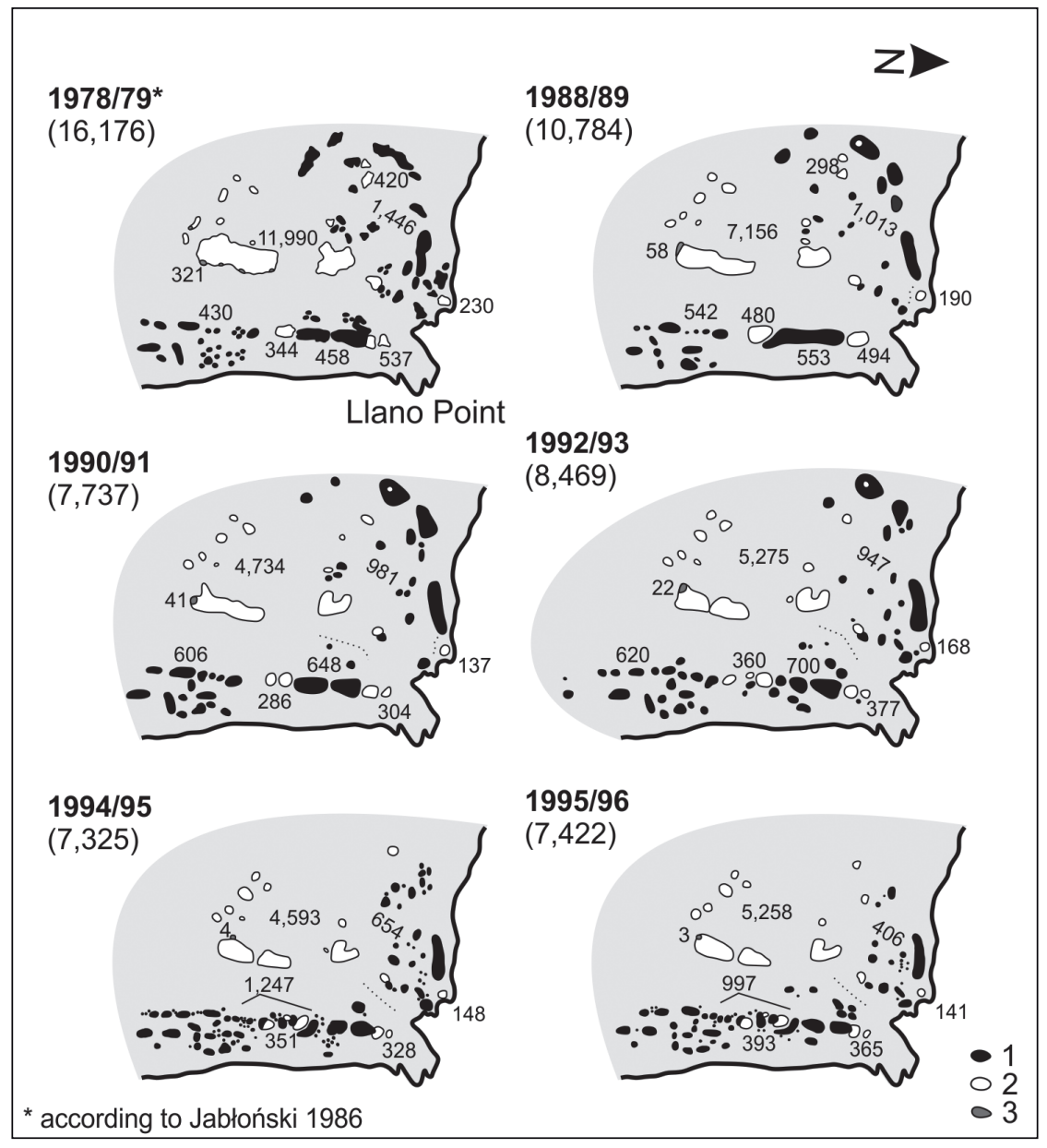

Fig. 4. Distribution of the breeding groups in Llano Point colony and the number of nests of three species of penguins in particular seasons between 1978 and 1996. Key to symbols: 1 - Pygoscelis papua, 2 - Pygoscelis adeliae, 3 - Pygoscelis antarcticus Total counts in parentheses.

Adélie Penguin (Pygoscelis adeliae). - The rookeries of Adélie Penguins were located on the western shore of the Admiralty Bay, within the Point Thomas (Fig. 3) and Llano Point (Fig. 4) oases (SSSI No. 8). In the 1978/79 breeding season 10,140 (Point Thomas) and 13,521 (Llano Point) nests were recorded. Each of these two colonies consisted of several breeding groups (Figs 3-4). The size of the Adélie Penguin population fluctuated in the following years (Table 2, Fig. 3-4). However, marked, although statistically insignificant, decrease in population size was recorded ( $\mathrm{n}=12$, Mann-Kendall's $S=-28, Z=1.852$, $P=0.06$ ). Moreover, a decrease of the Llano Point colony during the observation period was noted, while the size of Point Thomas population remained stable 
Table 2

Estimated numbers of pygoscelid penguin nests within the area of SSSI No. 8 in the years 1909, and 1957-1997, based on different sources.

\begin{tabular}{|c|c|c|c|l|}
\hline Season & $\begin{array}{c}\text { Pygoscelis } \\
\text { papua }\end{array}$ & $\begin{array}{c}\text { Pygoscelis } \\
\text { adeliae }\end{array}$ & $\begin{array}{c}\text { Pygoscelis } \\
\text { antarcticus }\end{array}$ & \multicolumn{1}{|c|}{ Reference } \\
\hline 1909 & 100 & 10500 & - & Myrcha 1993 (after Gain 1914) \\
\hline 1957 & 300 & 1500 & - & $\begin{array}{l}\text { Croxall and Kirkwood 1979 citing } \\
\text { unpublished Stephens 1957 }\end{array}$ \\
\hline 1965 & 2152 & 10200 & - & $\begin{array}{l}\text { Croxall and Kirkwood 1979 citing } \\
\text { White 1966 }\end{array}$ \\
\hline $77 / 78$ & 2600 & 18000 & - & Trivelpiece and Volkman 1979 \\
\hline $78 / 79$ & 3117 & 23661 & 7225 & Jabłoński 1984a \\
\hline $79 / 80$ & 3703 & 32918 & 5712 & Jabłoński 1984a \\
\hline $80 / 81$ & 2133 & 16405 & 4531 & Jabłoński 1984a \\
\hline $81 / 82$ & 2602 & 18046 & 5256 & Trivelpiece et al. 1987b \\
\hline $88 / 89$ & 2239 & 18838 & 3353 & Sierakowski 1991 \\
\hline $89 / 90$ & 2357 & 13965 & 2907 & Lesiński 1993 \\
\hline $90 / 91$ & 2401 & 15609 & 3026 & personal observation \\
\hline $91 / 92$ & 3385 & 17665 & 3185 & Zyska (personal commun.) \\
\hline $92 / 93$ & 2573 & 16259 & 3334 & personal observation \\
\hline $94 / 95$ & 2287 & 15151 & 2545 & personal observation \\
\hline $95 / 96$ & 1655 & 16788 & 2579 & personal observation \\
\hline $96 / 97$ & 1611 & 15637 & 2308 & personal observation \\
\hline
\end{tabular}

(Fig. 3). Breeding phenology data are presented in Table 3. After the breeding season penguins did not return to their colonies until the next spring. However, in those winters when the sea in the coastal area did not freeze, some individuals were observed occasionally. Adult birds did not moult before they left.

Chinstrap Penguin (Pygoscelis antarcticus). - There were six breeding colonies of Chinstrap Penguins in the Admiralty Bay area, with a total population size estimated at 10,339 nests in the season 1978/79. Five of the colonies (7,225 nests) were located within the SSSI No. 8, at the Point Thomas (Fig. 3), Llano Point (Fig. 4), Demay Point (Fig. 5), Uchatka Point (Fig. 6) and Patelnia Point oases (Fig. 7). The sixth colony was located on Chabrier Rock and Shag Island in the area of Vaureal Point, situated at the entrance to Admiralty Bay (Fig. 1). In the 1978/79 season, the size of this colony was estimated at 3,114 nests. There were 2,525 and 2,083 nests in the 1979/80 and 1980/81 seasons, respectively (Jabłoński 1984a, 1984b, 1986). A statistically significant decrease in the number of nests of Chinstrap Penguins was observed in the whole SSSI No. 8 area ( $\mathrm{n}=12$, Mann-Kendall's $S=-50, Z=3.360, P=0.0008$ ). There were over three times fewer breeding pairs in the 1996/1997 season compared with 1978/1979 (Table 2). The greatest decrease in the number of breeding pairs was observed in 


\begin{tabular}{|c|c|c|c|c|c|c|c|c|c|c|}
\hline \multicolumn{11}{|c|}{ 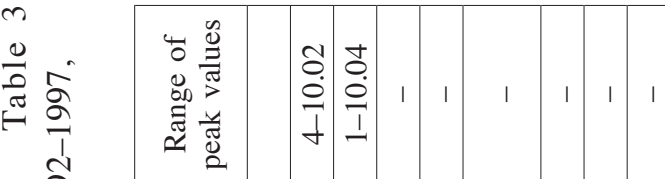 } \\
\hline $\begin{array}{l}a \\
\tilde{a} \\
\bar{a} \\
\bar{a} \\
\frac{1}{0}\end{array}$ & 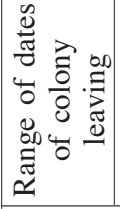 & 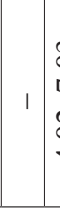 & 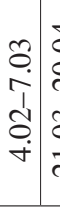 & 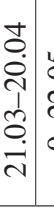 & $\begin{array}{l}n \\
0 \\
\text { ì } \\
1 \\
a\end{array}$ & 1 & 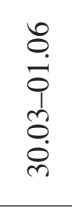 & 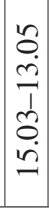 & 1 & 1 \\
\hline ô & 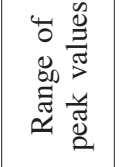 & 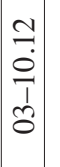 & j & 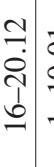 & $\begin{array}{l}\overline{0} \\
0 \\
1 \\
1\end{array}$ & 1 & 1 & 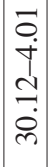 & $\begin{array}{c}\stackrel{1}{1} \\
i \\
I \\
-1\end{array}$ & 1 \\
\hline 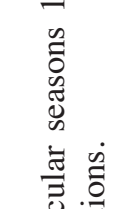 & 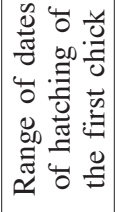 & 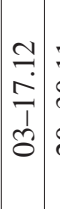 & 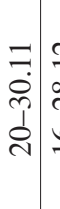 & 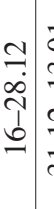 & 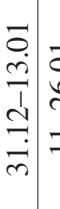 & 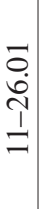 & $\begin{array}{l}\bar{o} \\
\text { ì } \\
\text { ì } \\
\text { ते }\end{array}$ & $\begin{array}{l}\sim \\
\sim \\
\sim \\
1 \\
\sim\end{array}$ & $\begin{array}{c}\mathcal{1} \\
\stackrel{2}{a} \\
i \\
n\end{array}$ & 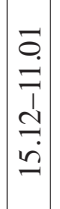 \\
\hline 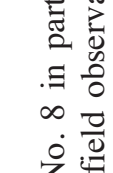 & 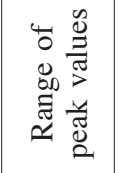 & 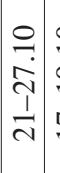 & 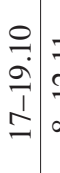 & $\begin{array}{c}= \\
\vec{a} \\
\mathfrak{I} \\
1 \\
\infty\end{array}$ & 1 & 1 & 1 & $\begin{array}{l}= \\
a \\
a \\
1 \\
-1\end{array}$ & $\mid \begin{array}{c}= \\
\vdots \\
1 \\
1 \\
0\end{array}$ & I \\
\hline 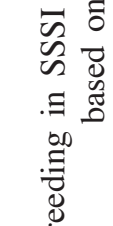 & 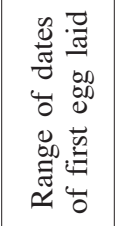 & 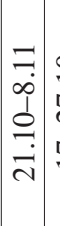 & 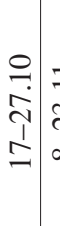 & $\begin{array}{ll} & \\
z & \\
& \\
\infty & \\
\infty & \\
\vdots\end{array}$ & 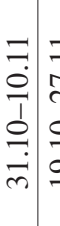 & $\begin{array}{l}= \\
\vdots \\
\hat{v} \\
0 \\
a \\
a\end{array}$ & 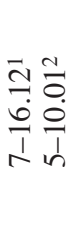 & $\begin{array}{l}= \\
a \\
a \\
1 \\
0 \\
\vdots \\
a\end{array}$ & 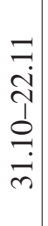 & $\begin{array}{l}= \\
\vec{T} \\
b\end{array}$ \\
\hline 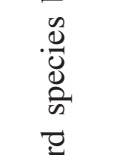 & 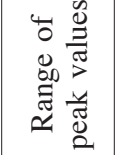 & 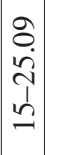 & 1 & 1 & 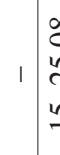 & $\begin{array}{l}\infty \\
0 \\
\qquad \\
\\
1 \\
n\end{array}$ & $\begin{array}{l}= \\
\frac{n}{n} \\
m\end{array}$ & 1 & 1 & 1 \\
\hline $\begin{array}{l}40 \\
\text { के } \\
0 \\
0 \\
0 \\
\frac{0}{0} \\
\frac{0}{2}\end{array}$ & 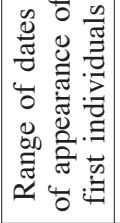 & 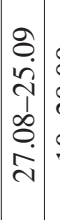 & 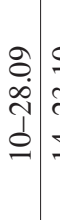 & 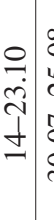 & 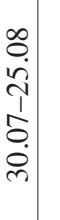 & 1 & 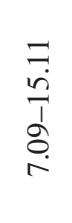 & $\begin{array}{c}0 \\
\cdots \\
\dot{\lambda} \\
1 \\
\alpha \\
\alpha\end{array}$ & $\begin{array}{c}2 \\
0 \\
a \\
1 \\
n \\
-\end{array}$ & \begin{tabular}{l}
8 \\
\multirow{1}{*}{} \\
$\infty$ \\
$\infty$
\end{tabular} \\
\hline 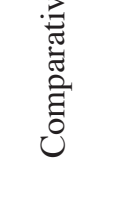 & & $\begin{array}{c}\mathfrak{3} \\
\mathfrak{Z} \\
\vdots \\
\vdots \\
0\end{array}$ & 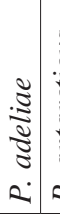 & 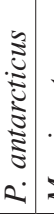 & 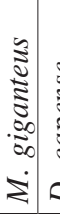 & $\begin{array}{c}0 \\
\vdots \\
\vdots \\
\vdots \\
\vdots \\
0 \\
0\end{array}$ & 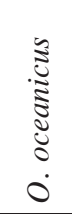 & $\begin{array}{c}\dot{0} \\
0 \\
\vdots \\
\cdot \vdots \\
\vdots \\
\vdots \\
0 \\
\vdots \\
\vdots \\
\vdots \\
\vdots\end{array}$ & 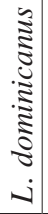 & 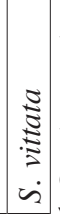 \\
\hline
\end{tabular}




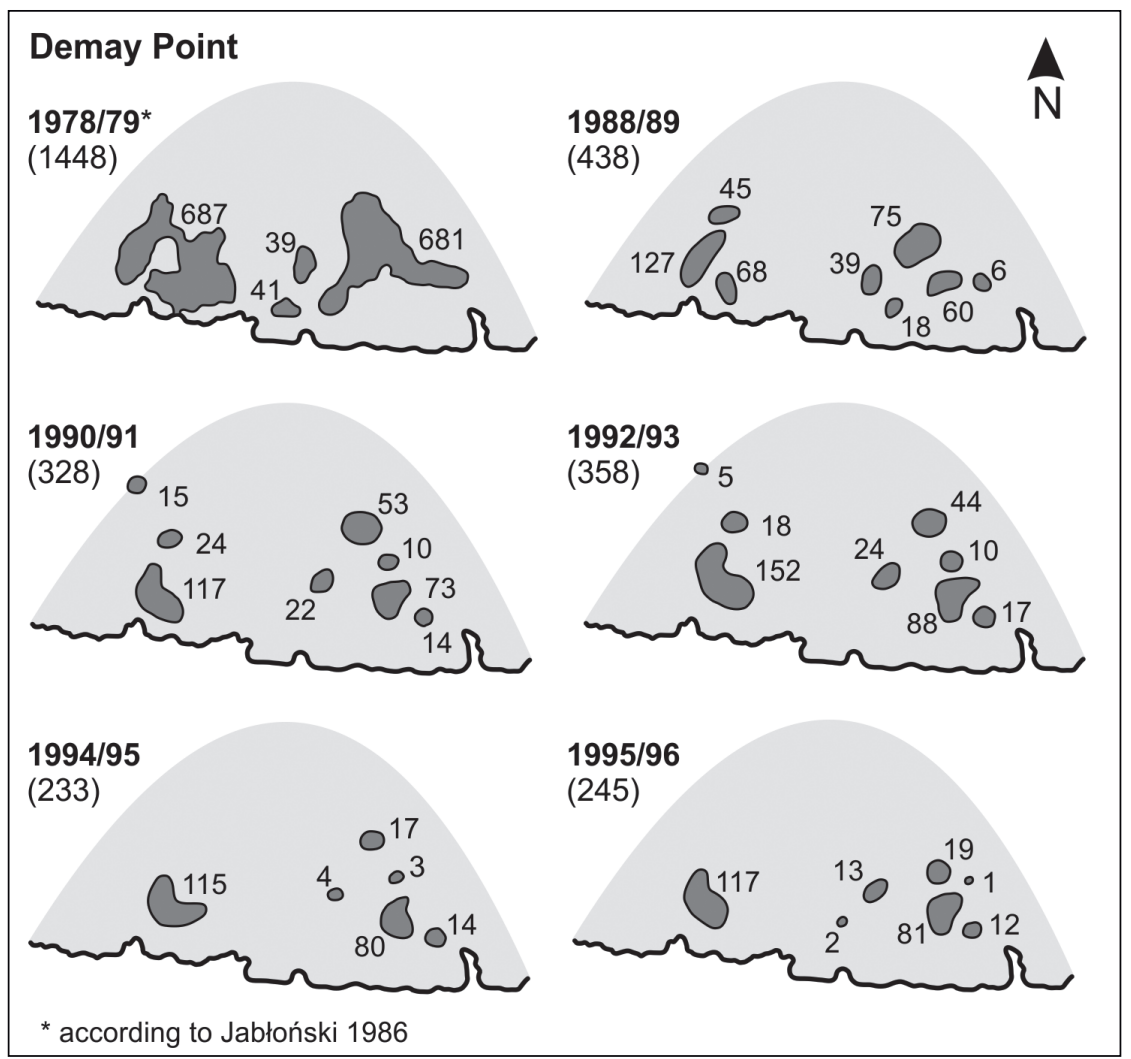

Fig. 5. Distribution of the breeding groups in Demay Point colony and the number of nests of Pygoscelis antarcticus in particular seasons between 1978 and 1996. Total counts in parentheses.

the Point Thomas (Fig. 3) and Llano Point colonies (Fig. 4). After the breeding period, adult penguins moulted and then left the Admiralty Bay area. They were not observed during the winter. Breeding phenology data are presented in Table 3.

Southern Giant Petrel (Macronectes giganteus). - There were three breeding colonies situated on moraines at the oases of Point Thomas, Rescuers Hills, and Vaureal Point (Fig. 1, Table 4). Some individuals bred outside these colonies. In the Point Thomas oasis, a breeding group located at so-called Jedynka (in the vicinity of Station's fuel tank) was abandoned, probably due to an excessive human activity in the Arctowski Station. This group consisted of about 17 nests in 1978 (Jabłoński 1986) and 11 nests in 1980 (Wasilewski, personal commun.) and only two nests were observed in 1984 (Myrcha 1993). In 1987, there was only a single nest that persisted until the 1990/1991 season. Breeding phenology data are presented in Table 3. The largest breeding colony in the SSSI No. 8 , comprising $85 \%$ of all Southern Giant Petrel nests recorded 


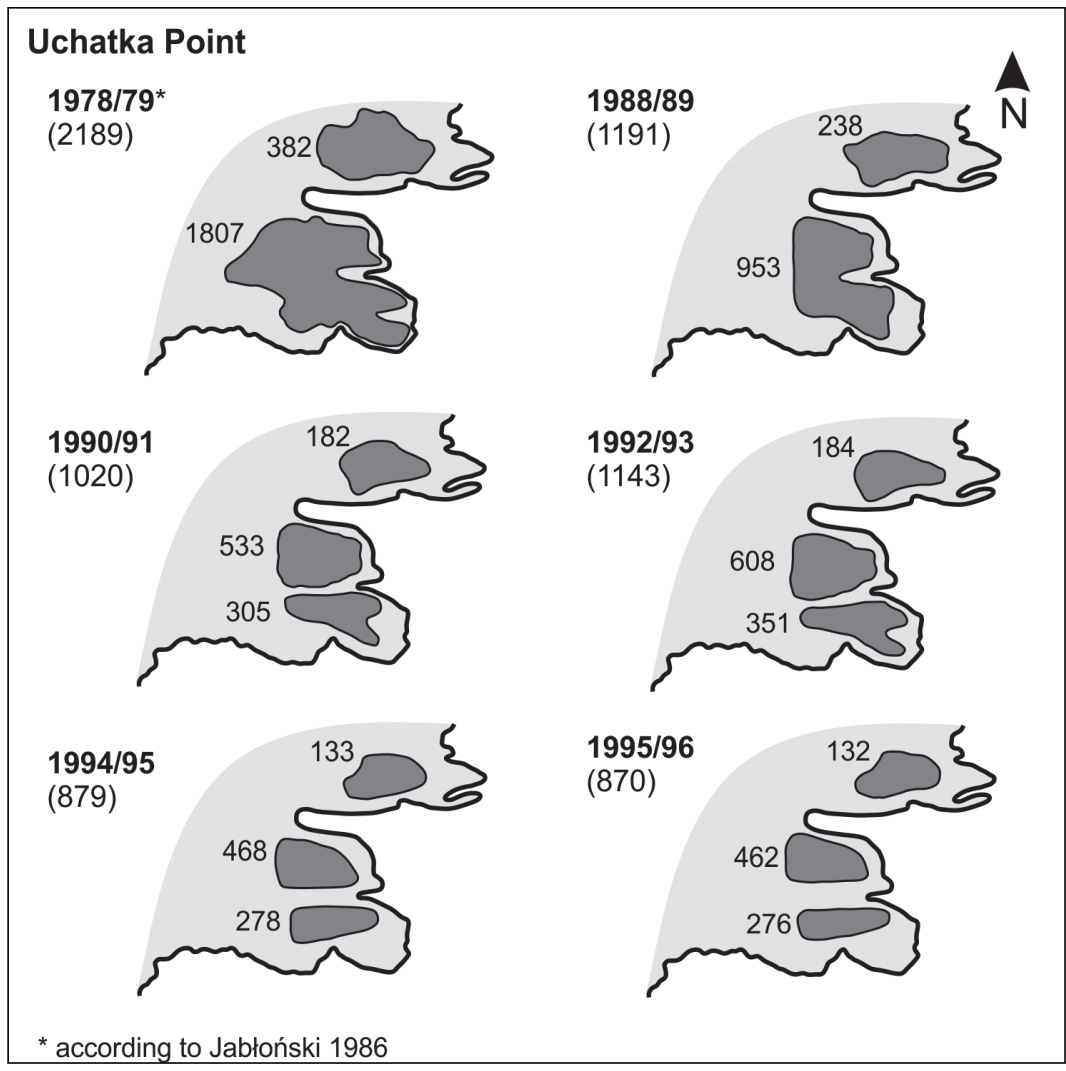

Fig. 6. Distribution of the breeding groups in Uchatka Point colony and the number of nests of Pygoscelis antarcticus in particular seasons between 1978 and 1996. Total counts in parentheses.

within this area, was located on moraines of the Rescuers Hills and Llano Point. At the Vaureal Point, the largest breeding colony in the Admiralty Bay area, the number of nests varied from 113 to 236 between 1979 and 1996. A part of the population of Southern Giant Petrels stayed in the investigated area throughout the year. Wintering birds most frequently spent nights in the area of breeding sites. However, ringing recoveries revealed that young birds banded at the Vaureal Point and Penguin Island may also migrate in the eastern direction, visiting Australian and New Zealand shores during their migration around Antarctica (Fig. 8). The longest flight was made by a young bird and covered the distance from King George Island to New Zealand (at least 16 thousand $\mathrm{km}$ ) within 74 days. Considering all (682) chicks of Southern Giant Petrels banded by Andrzej Myrcha in 1985 and Kazimierz Sierakowski in 1988, 1992, and 1995, recoveries were obtained for 12 birds. These individuals were found on the eastern coast of Australia (e.g. Fraser Island, Brisbane, Queensland; Tasman 


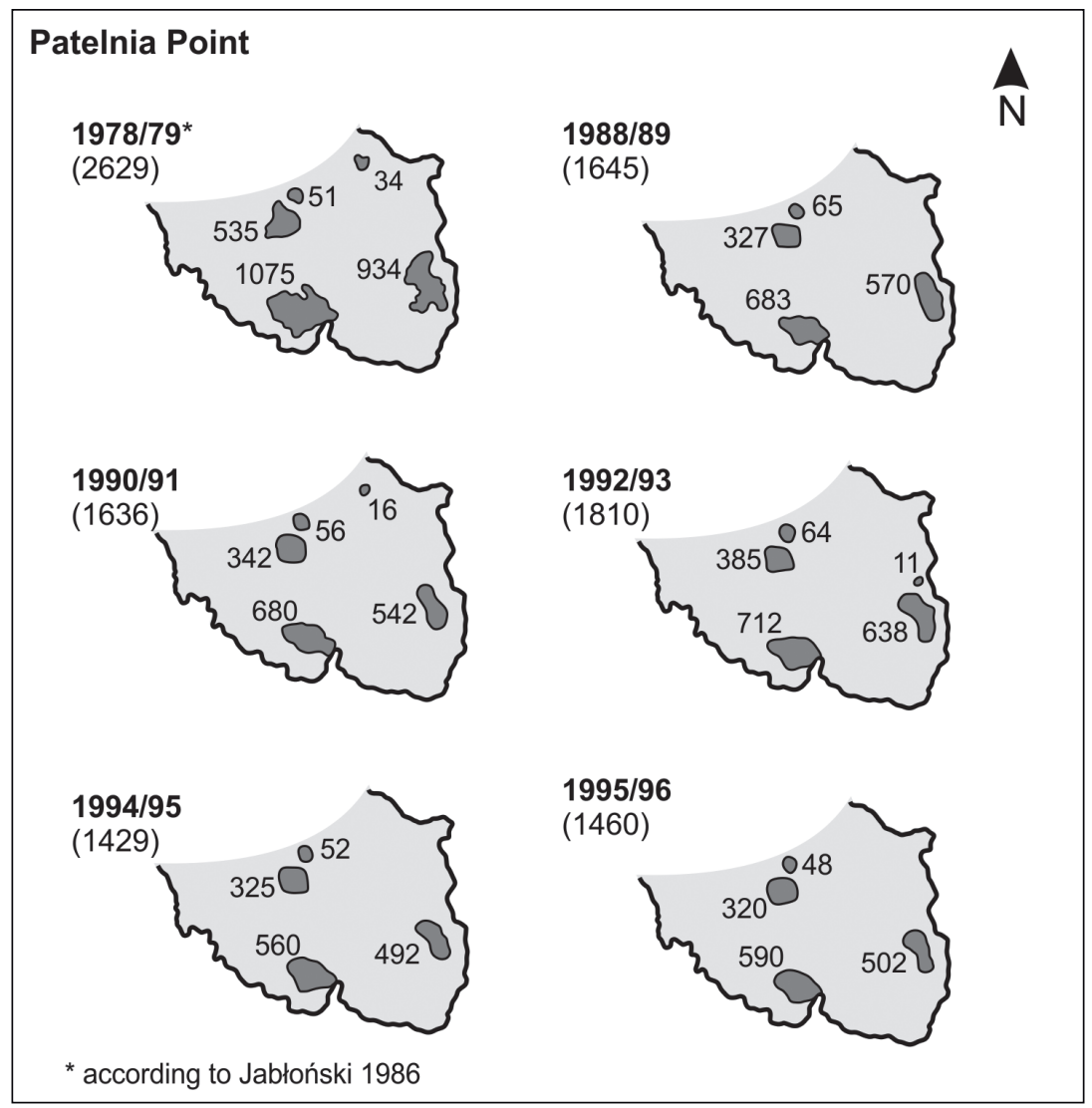

Fig. 7. Distribution of the breeding groups in Patelnia Point colony and the number of nests of Pygoscelis antarcticus in particular seasons between 1978 and 1996. Total counts in parentheses.

Sea, Wollongong; between Camden and Diamond Heads), the northern coast (e.g. Mile Beach; Ohui Beach) and the southern coast (e.g. Kaikoura) of New Zealand 74-88 days after departure from the nest.

Cape Petrel (Daption capense). - Four breeding sites of this species were located within the SSSI No. 8. The largest breeding colony occupied the rock shelves on Demay Point (Table 5). In addition, some breeding pairs were observed within the areas of Vaureal Point, Chabrier Rock, and Hennequin Point (Fig. 1). Cape Petrels usually returned to their breeding colonies in the middle of September. The spring arrival was frequently synchronized (Sierakowski 1991). Mating began in late September (Table 3). Small flocks consisting of a few individuals feeding by the waterside were observed for a long time after the breeding season (Presler 1980; Sierakowski 1991; Lesiński 1993; Myrcha 1993). Cape Petrels left the site when the bay froze. 
$\frac{1}{\frac{1}{6}}$

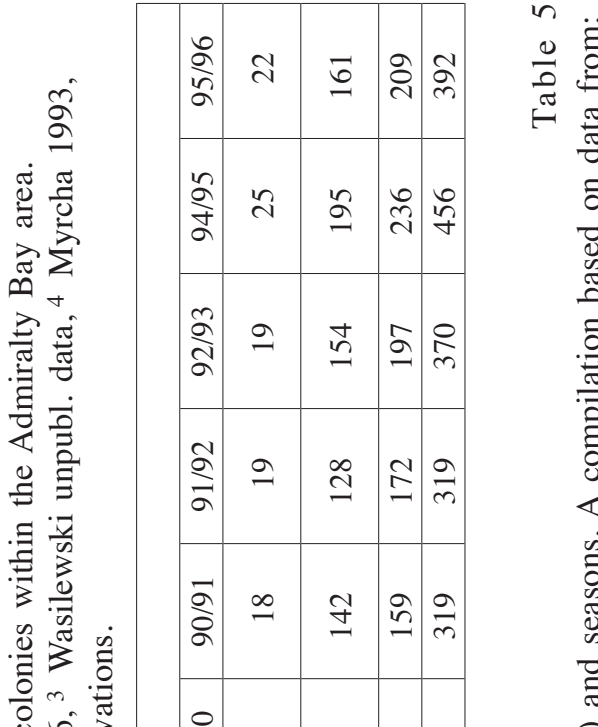

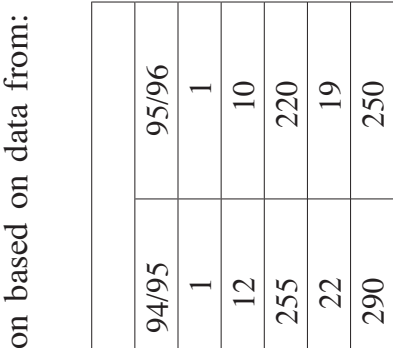

$=\infty$

$=\frac{1}{0}$

\begin{tabular}{|c|c|c|c|}
\hline ڤa & $\infty$ & $\sqrt{6}$ & a. \\
\hline \begin{tabular}{l|l}
0 \\
0 \\
$\infty$ \\
$=0$ \\
$=0$ & $\infty$ \\
$\infty$ & $\infty$ \\
$\infty$
\end{tabular} & I & $\stackrel{n}{ \pm}$ & 总 \\
\hline
\end{tabular}

要

《

$\dot{0} 0$

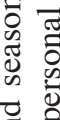

急

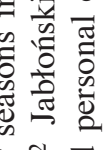

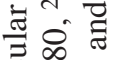

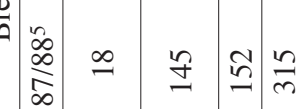

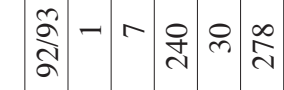

究命

$\Xi \pm \frac{\nabla}{\omega}$

芯

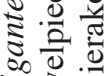

कo 2 in

虾

¿ั.

ธิ

之

पै

๑

\&

औิ

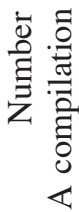

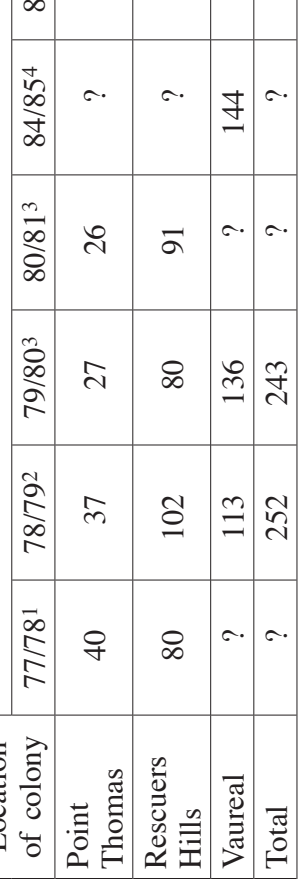

之ั

जे:

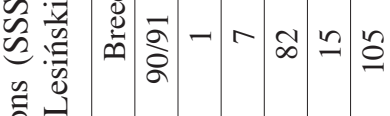

的

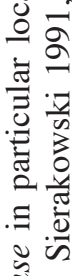

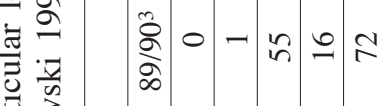

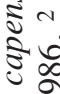

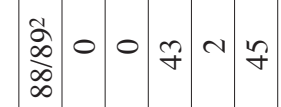

范

尝

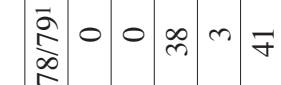

-

כֶ,

4

है

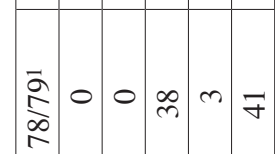

\begin{tabular}{|l|l|l|l|l|l|}
\hline & & & & & \\
\hline
\end{tabular}

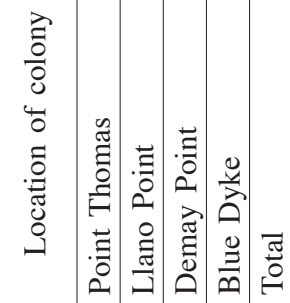




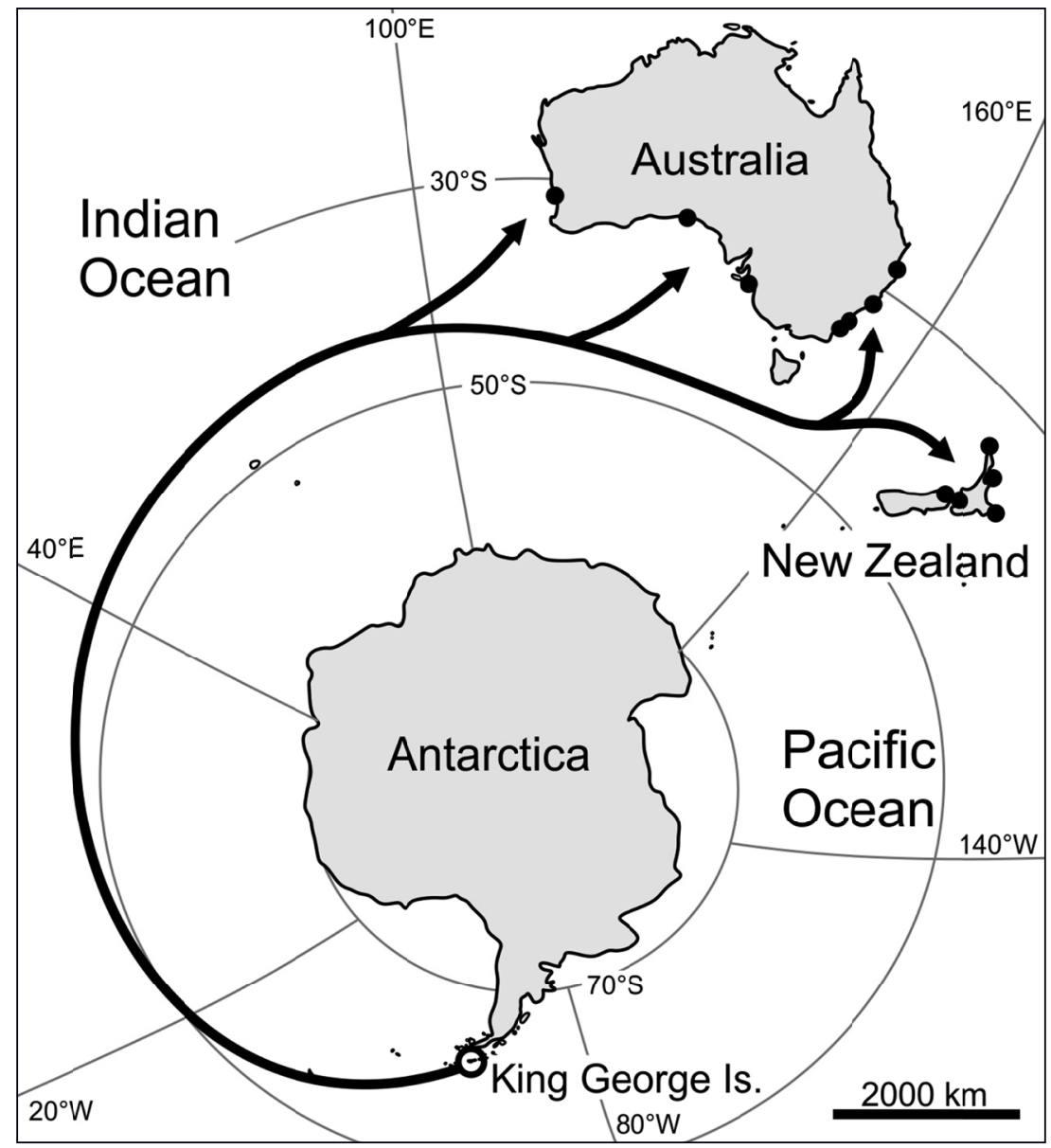

Fig. 8. Flight direction and records of Macronectes giganteus banded on King George Island.

Wilson's Storm Petrel (Oceanites oceanicus). - This species was one of the most common breeding species of the Admiralty Bay area, occurring in all oases along its coast. The preferred breeding biotope of Wilson's Storm Petrels was the rock rubble made of andesite and basalts on the northern slopes. They also built their nests in rock crevices of cliffs, under large boulders and whale bones. Breeding activity in nests located in the rock rubble on the southern slopes began much later due to the longer snow retention and delayed drying of the ground between stone heaps. The population size assessment was very difficult due to the fact that birds were active at night. During the 1978/1979 season, there were two thousand pairs nesting in the SSSI No. 8 area (Jabłoński 1986), while the breeding population of the entire Admiralty Bay area was estimated 
at 3,400 pairs in 1979/1980 (Wasilewski 1986). In two seasons, 1988/1989 (Sierakowski 1991) and 1994/1995, eight breeding colonies of Wilson's Storm Petrels were recorded between Jardine Peak and Patelnia Point (Jardine Peak Point Thomas, Shag Point - Rakusa Point, Llano Point, Sphinx Hill - Zamek, Demay Point, Uchatka Point, Blue Dyke, Patelnia Point) (see Fig. 2). However, more than $50 \%$ of nesting birds were breeding in Jardine Peak - Point Thomas oasis in both seasons. Notes on phenology of this species are presented in Table 3 .

Black-bellied Storm Petrel (Fregetta tropica). - In the SSSI No. 8 area these birds were hardly numerous and often bred in mixed colonies with Wilson's Storm Petrels. Both species had similar activity periods and reproduction phenology. The largest breeding aggregation of Black-bellied Storm Petrels (a mixed colony) in the Admiralty Bay area was located on the slopes of the Jersak Peak. In the 1978/1979 season, it consisted of $c a .250$ individuals (Jabłoński 1986), whereas during the 1979/1980 and 1980/1981 breeding seasons, about 320 individuals were nesting there (Wasilewski 1986). In the seasons 1988/1989 (Sierakowski 1991) and 1994/1995, single nesting pairs of the Black-bellied Storm Petrel were also recorded between Shag Point and Rakusa Point, within Llano Point, between Sphinx Hill and Zamek, and within Demay Point, Uchatka Point, Blue Dyke, Patelnia Point oases (see Fig. 2). However, in both seasons more than $90 \%$ of the whole breeding population nested within the Point Thomas and Jardine Peak oasis. The first post-winter appearance of Black-bellied Storm Petrels was recorded between 9 September and 16 November (Table 3). However, the majority of returning individuals were recorded in the first half of November. The phenology of the reproduction of Black-bellied Storm Petrels was similar to that of Wilson's Storm Petrels.

Antarctic Shag (Phalacrocorax atriceps bransfieldensis). - The breeding colony was located on Shag Island (Vaureal Point) (Fig. 1). The colony size was rather stable and reached the maximum number of 128 breeding pairs (Table 6). Additionally one pair was observed breeding in Herve Cove in $1987 / 88$. Moreover, up to 100 adult non-breeding individuals usually stayed in the Admiralty Bay area during the breeding season (Myrcha 1993). After the breeding season, flocks of shags, usually consisting of about a dozen individuals, were seen, until the bay was entirely frozen. A flock of 155 birds was observed on June 1989 in the Point Thomas area (Lesiński 1993).

Pale-faced Sheathbill (Chionis albus). - These birds built their nests in niches within the rock rubble in the vicinity of penguin colonies. Due to their strong territoriality, they did not occur in great numbers and their numbers varied from 27 to 63 individuals. In the SSSI No. 8, birds nested in a few oases (Table 7). Nesting birds were also recorded in the Vaureal Point and Chabrier Rock area. Sheathbills began to form pairs in the middle of September. The 
Table 6

Number of breeding pairs of Phalacrocorax atriceps bransfieldensis in particular seasons in Admiralty Bay area. A compilation based on data from: ${ }^{1}$ Jabłoński 1986,

2 Myrcha 1993, ${ }^{2}$ Sierakowski 1991, ${ }^{4}$ Lesiński 1993 and personal observations.

\begin{tabular}{|c|c|c|c|c|c|c|c|c|c|}
\hline \multirow{2}{*}{$\begin{array}{c}\text { Location } \\
\text { of colony }\end{array}$} & \multicolumn{8}{|c|}{ Breeding seasons } \\
\cline { 2 - 11 } & $78 / 79^{1}$ & $84 / 85^{2}$ & $87 / 88^{3}$ & $88 / 89^{3}$ & $89 / 90^{4}$ & $90 / 91$ & $92 / 93$ & $94 / 95$ & $95 / 96$ \\
\hline Shag Island & 114 & 96 & 97 & 83 & 96 & 122 & 128 & 86 & 108 \\
\hline
\end{tabular}

construction of nests started early in October. Egg laying began at the end of November and ended in the middle of December. After the breeding period, a large part of the population wintered, from the beginning of April until the end of October, in the vicinity of the Arctowski Station (Fig. 9). Many of the observed wintering sheathbills were banded. Identification of marked birds showed that some individuals came from different areas of the island. There was also a winter movement of birds between some Antarctic stations or other places providing an access to human food waste.

South Polar Skua (Stercorarius maccormicki). - These birds occurred in small numbers in the SSSI No. 8, on moraine hills covered by tundra. Some non-breeding individuals were also observed in the summer season. These were mainly juvenile birds staying in the vicinity of freshwater ponds situated near the Arctowski Station.

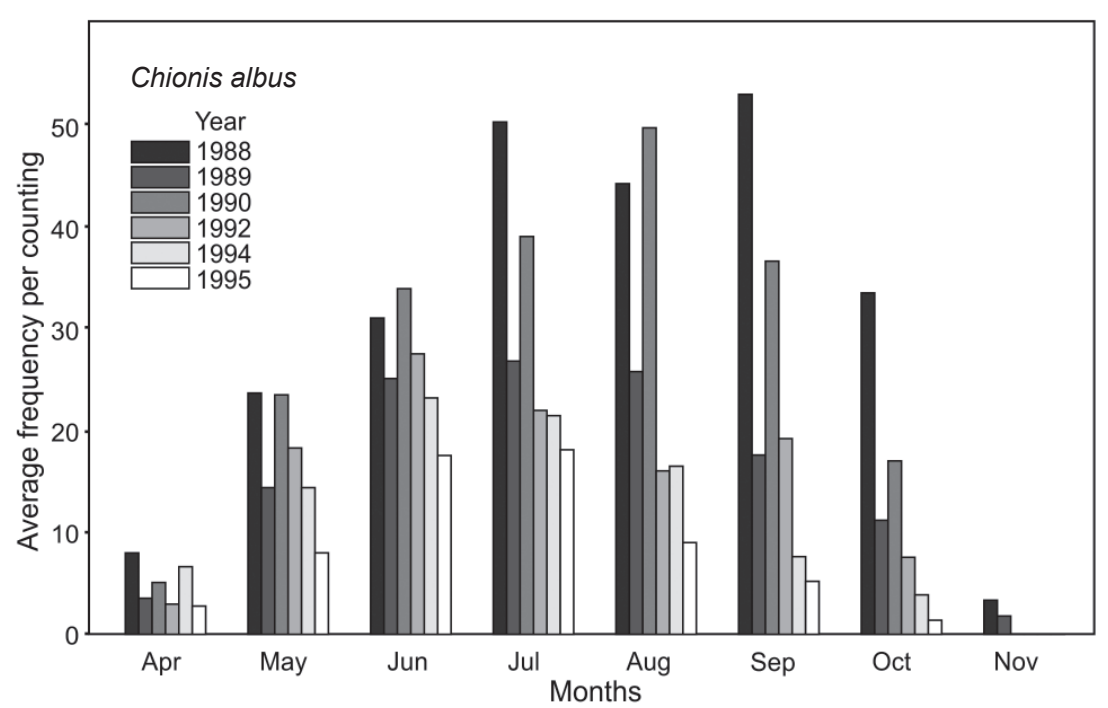

Fig. 9. Number (average frequency per counting) of Chionis albus individuals observed in the vicinity of the Arctowski Station during five winter seasons (from April to November). 


\section{Table 7}

Number of nests of Chionis albus in particular locations (SSSI No 8) and seasons. A compilation based on data from: ${ }^{1}$ Trivelpiece et al. 1980, ${ }^{2}$ Jabłoński 1986,

3 Sierakowski 1991, ${ }^{4}$ Lesiński 1993 and personal observations.

\begin{tabular}{|l|c|c|c|c|c|c|c|c|c|}
\hline \multirow{2}{*}{$\begin{array}{c}\text { Location } \\
\text { of nests }\end{array}$} & \multicolumn{8}{|c|}{ Breeding seasons } \\
\cline { 2 - 12 } & $77 / 78^{1}$ & $78 / 79^{2}$ & $88 / 89^{3}$ & $89 / 90^{4}$ & $90 / 91$ & $91 / 92$ & $92 / 93$ & $94 / 95$ & $95 / 96$ \\
\hline Point Thomas & 9 & 12 & 5 & 2 & 5 & 3 & 2 & 0 & 0 \\
\hline Rescuers Hills & 3 & 1 & 1 & 3 & 3 & 4 & 3 & 2 & 2 \\
\hline Sphinx-Siodło & $?$ & 0 & 2 & 0 & 1 & 1 & 1 & 0 & 0 \\
\hline Demay Point & $?$ & 1 & 1 & 1 & 1 & 0 & 0 & 0 & 0 \\
\hline Blue Dyke & $?$ & 0 & 0 & 2 & 1 & 1 & 0 & 0 & 0 \\
\hline Total & $?$ & 14 & 9 & 8 & 11 & 9 & 6 & 2 & 2 \\
\hline
\end{tabular}

Brown Skua (Stercorarius antarctica). - This species was more numerous in comparison with $S$. maccormicki and was observed within almost the entire SSSI No. 8, especially in the vicinity of the penguin colonies. A sub-species, Stercorarius antarcticus lonnbergi, was also recorded in this area. Each summer, a large population of non-breeding individuals, mainly juvenile birds, flocked near freshwater ponds located in the vicinity of the Arctowski Station. Their numbers often exceeded 200 individuals mixed with non-breeding South Polar Skuas. Both species sometimes form mixed breeding pairs that always consists of S. antarcticus lonnbergi females and S. maccormicki males (Trivelpiece and Volkman 1982). Such breeding attempts are often successful and the offspring (hybrids) are fertile. Since some observations did not consider subtle differences in plumage between $S$. maccormicki, S. antarcticus and hybrids, data concerning skua distribution, number of breeding pairs and phenology have been presented altogether as Stercorarius sp. (Table 3,8). Skuas bred not only within SSSI No. 8 but also at the whole ice free area of western shore of Admiralty Bay.

Kelp Gull (Larus dominicanus). - This species was observed in the larger oases of SSSI No. 8 (Table 9). Both breeding and non-breeding birds (Table 3) were observed.

Small breeding clusters of loosely spaced nests were usually situated on small rocks and moraines in the vicinity of the sea. A large part of the population wintered in the vicinity of the Arctowski Station (Fig. 10). The maximum number of wintering gulls was 166 individuals observed in 1988. From 1990, a decrease in the number of wintering birds has been observed and their maximum numbers in following years varied from 34 to 68 . Kelp Gulls bred not only within SSSI No. 8, but also at the whole ice free area of Admiralty Bay. 
Table 8

Number of breeding pairs of Stercorarius sp. in particular locations (SSSI No 8) and seasons. A compilation based on data from: 1 Trivelpiece et al. 1980,

2 Jabłoński 1986, ${ }^{3}$ Sierakowski 1991, ${ }^{4}$ Lesiński 1993 and personal observations.

\begin{tabular}{|l|c|c|c|c|c|c|c|c|c|}
\hline \multirow{2}{*}{\begin{tabular}{c}
\multirow{2}{*}{$\begin{array}{c}\text { Location } \\
\text { of nests }\end{array}$} \\
\cline { 2 - 12 }
\end{tabular}} & $77 / 78^{1}$ & $78 / 79^{2}$ & $88 / 89^{3}$ & $89 / 90^{4}$ & $90 / 91$ & $91 / 92$ & $92 / 93$ & $94 / 95$ & $95 / 96$ \\
\hline Point Thomas & 28 & 38 & 21 & 31 & 21 & 38 & 38 & 34 & $?$ \\
\hline Rescuers Hills & 17 & 11 & 8 & 12 & 17 & 14 & 14 & 9 & $?$ \\
\hline Sphinx - Siodło & $?$ & 3 & 2 & 1 & 4 & 2 & 3 & 4 & $?$ \\
\hline Demay Point & \multirow{2}{*}{$?$} & 10 & 3 & 2 & 11 & 8 & 10 & 8 & $?$ \\
\cline { 1 - 13 } Uchatka Point & $?$ & 5 & 2 & 4 & 3 & 4 & 5 & 4 & $?$ \\
\hline Blue Dyke & $?$ & 2 & 1 & 3 & 2 & 2 & 2 & 2 & 2 \\
\hline Patelnia Point & $?$ & 69 & 38 & 57 & 62 & 71 & 75 & 64 & $?$ \\
\hline Total & $?$ & & & 4 & 4 & 3 & 3 & 3 & $?$ \\
\hline
\end{tabular}

Table 9

Number of breeding pairs of Larus dominicanus in particular locations (SSSI No 8) and seasons. A compilation based on data from: ${ }^{1}$ Trivelpiece et al. 1980,

2 Jabłoński 1986, ${ }^{3}$ Myrcha 1993, 4 Sierakowski 1991, ${ }^{5}$ Lesiński 1993 and personal observations.

\begin{tabular}{|l|c|c|c|c|c|c|c|c|c|c|}
\hline \multirow{2}{*}{$\begin{array}{c}\text { Location } \\
\text { of nests }\end{array}$} & \multicolumn{8}{|c|}{ Breeding seasons } \\
\cline { 2 - 14 } & $77 / 78^{1}$ & $78 / 79^{2}$ & $85 / 86^{3}$ & $88 / 89^{4}$ & $89 / 90^{5}$ & $90 / 91$ & $91 / 92$ & $92 / 93$ & $94 / 95$ & $95 / 96$ \\
\hline Point Thomas & 11 & 22 & $?$ & 10 & 16 & 13 & 8 & 11 & 14 & 13 \\
\hline Llano Point & 2 & 8 & $?$ & 12 & 9 & 8 & 5 & 8 & 6 & 6 \\
\hline $\begin{array}{l}\text { Sphinx } \\
- \text { Siodło }\end{array}$ & $?$ & 6 & $?$ & 3 & 2 & 8 & 6 & 6 & 4 & 6 \\
\hline Demay Point & $?$ & 16 & $?$ & 22 & 10 & 11 & 12 & 14 & 9 & 9 \\
\hline Blue Dyke & $?$ & 7 & $?$ & 5 & 7 & 6 & 5 & 6 & 5 & 4 \\
\hline Patelnia Point & $?$ & 0 & 30 & 0 & 3 & 5 & 9 & 12 & 8 & 8 \\
\hline Total & $?$ & 59 & $?$ & 52 & 47 & 51 & 45 & 57 & 46 & 46 \\
\hline
\end{tabular}

Antarctic Tern (Sterna vittata). - These birds bred in all large oases of SSSI No. 8 (Table 10). The size of breeding groups ranged from a few up to several dozen scattered nests located on moraines and mild slopes with fine rubble. The breeding phenology (Table 3 ) of the Antarctic Tern was protracted and the size of its population was subject to seasonal fluctuations. During the winter icing Antarctic Terns moved away to open waters. However, when Admiralty Bay did not freeze, small flocks of feeding birds were observed. The number 


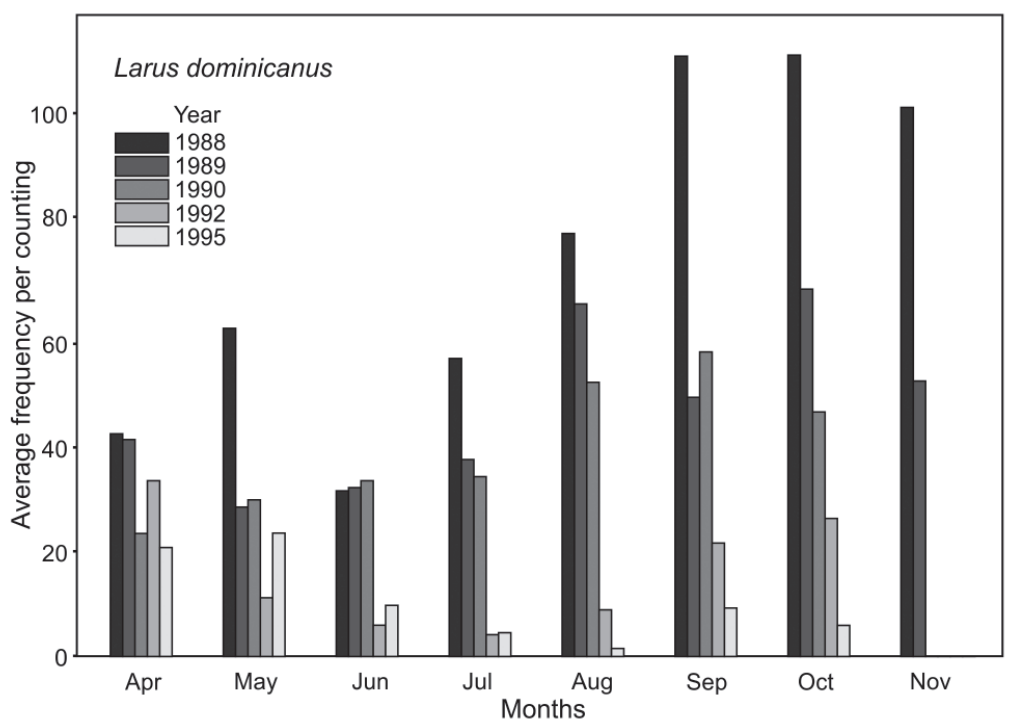

Fig. 10. Number (average frequency per counting) of Larus dominicanus individuals observed in the vicinity of the Arctowski Station during five winter seasons (from April to November).

Table 10

Number of breeding pairs of Sterna vittata in particular locations (SSSI No 8) and seasons. A compilation based on data from: ${ }^{1}$ Jabłoński 1995, ${ }^{2}$ Myrcha 1993,

3 Sierakowski 1991, ${ }^{4}$ Lesiński 1993 and personal observations.

\begin{tabular}{|l|r|r|r|r|r|r|r|r|r|r|}
\hline \multirow{2}{*}{$\begin{array}{l}\text { Location } \\
\text { of nests }\end{array}$} & \multicolumn{9}{|c|}{ Breeding seasons } \\
\cline { 2 - 13 } & $78 / 79^{1}$ & $79 / 80^{1}$ & $80 / 81^{1}$ & $85 / 86^{2}$ & $88 / 89^{3}$ & $89 / 90^{4}$ & $90 / 91$ & $92 / 93$ & $94 / 95$ & $95 / 96$ \\
\hline $\begin{array}{l}\text { Point } \\
\text { Thomas }\end{array}$ & 34 & 90 & 58 & $?$ & 13 & 6 & 28 & 65 & 33 & 33 \\
\hline $\begin{array}{l}\text { Rescuers } \\
\text { Hills }\end{array}$ & 4 & 2 & 2 & $?$ & 0 & 9 & 5 & 3 & 0 & 0 \\
\hline $\begin{array}{l}\text { Sphinx- } \\
\text { Siodło }\end{array}$ & 8 & 62 & 82 & $?$ & 10 & 25 & 7 & 15 & 3 & 3 \\
\hline Demay Point & - & - & - & $?$ & 110 & 40 & 70 & 62 & 58 & 67 \\
\hline $\begin{array}{l}\text { Uchatka } \\
\text { Point }\end{array}$ & 152 & 363 & 218 & $?$ & 15 & 22 & 24 & 16 & 25 & 17 \\
\hline Blue Dyke & 159 & & 16 & $?$ & 25 & 8 & 6 & 9 & 15 & 10 \\
\hline $\begin{array}{l}\text { Patelnia } \\
\text { Point }\end{array}$ & 20 & 39 & 30 & 50 & 15 & 33 & 27 & 37 & 1 & 2 \\
\hline Total & 377 & 556 & 406 & $?$ & 188 & 143 & 167 & 207 & 135 & 132 \\
\hline
\end{tabular}

of Antarctic Terns remaining within bay waters increased even up to a few hundred individuals during the winter storms, when the wind blew from the north (Myrcha 1993; Lesiński 1993). Beyond SSSI No. 8, Antarctic Terns bred at the whole ice free area of Admiralty Bay. 
Non-breeding birds visiting regularly

Macaroni Penguin (Eudyptes chrysolophus). - One to three individuals were observed within the SSSI No. 8 area, almost every year (Presler 1980; Jabłoński 1986; Lesiński 1993). According to Trivelpiece et al. (1987a), these birds appeared from the middle to the end of the summer in the area of Point Thomas and Llano Point. They were also recorded regularly in 1988, 1990, 1991, 1993, and 1995 at Point Thomas, Llano Point and Patelnia Point, between mid Dec and Feb.

Southern Fulmar (Fulmarus glacialoides). - One to three individuals were regularly observed within the Admiralty Bay, in the area of Point Thomas, in Jan 1979 (Jabłoński 1986), in Sep 1988, in Apr, Sep, Oct 1989; (Lesiński 1993) and also in Feb 1990, summer season 1991, Aug 1992 and Sep 1995. On 3 October 1995, about a dozen birds were recorded flying over the bay.

Snow Petrel (Pagodroma nivea). - A few individuals were observed flying over the bay in Feb 1979 for the first time (Jabłoński 1986). Since 1988, this species was observed many times during winter storms when the bay was free of ice. Since 1989 , from three to twenty two individuals were frequently observed mostly during the winter season (Lesiński 1993).

Arctic Tern (Sterna paradisaea). - This species was regularly recorded in the Admiralty Bay area. Between three to nine individuals were observed during the summer season of 1990 (Nov), 1992 (Jan) and 1995 (Feb and Nov).

Non-breeding birds visiting rarely

Southern Rockhopper Penguin (Eudyptes chrysocome). - Single individuals were observed during the 1985, 1986, 1987, 1988, 1993 and 1995 summer (Nov to Feb), mostly at Point Thomas, Uchatka Point and Patelnia Point. In Jan-Feb 1987 (Trivelpiece et al. 1987a) and Feb 1988 single individuals were seen moulting at Point Thomas.

Black-browed Albatross (Thalassarche melanophris). - Single individuals were observed in Feb in 1989 and 1990 within the Admiralty Bay area (Lesiński 1993) and in Jan 1991 and Feb 1995 between Llano Point and Demay Point.

Antarctic Petrel (Thalassoica antarctica). - These birds were observed in the Admiralty Bay area between Feb and Jul. Single individuals were recorded in 1990 (Lesiński 1993), 1992 and 1995. Moreover, five individuals were recorded in Oct 1995.

Black-necked Swan (Cygnus melancoryphus). - A single individual was recorded in Jan and Feb of 1989 on the freshwater lake near the Arctowski Station and in Admiralty Bay (Sierakowski 1991; Lesiński 1993). Single individuals were observed, within the same area, in Dec of 1992, 1994 and Apr 1995. 
Yellow-billed Pintail (Anas georgica). - Twenty individuals were recorded in Oct 1985 in the area of Point Thomas (Trivelpiece et al. 1987a). In 1995, at the end of Oct and beginning of Nov, between seven and thirteen individuals were observed at Point Thomas.

White-rumped Sandpiper (Calidris fuscicollis). - Twenty five individuals were observed in the area of Point Thomas, by the colony of Adélie Penguins, from Oct 1985 to Feb 1986. During the summer of 1986/87, a single individual was recorded at Sphinx Hill (Trivelpiece et al. 1987a). In Nov 1990, between four and nine individuals were seen at Point Thomas and Llano Point, and two individuals were observed in Nov 1995 at Point Thomas.

Non-breeding birds visiting occasionally

King Penguin (Aptenodytes patagonicus). - One individual was recorded near the Arctowski Station fuel tank on 11 Jan 1990 (Lesiński 1993).

Emperor Penguin (Aptenodytes forsteri). - Single individuals were observed in Jun 1977 (Presler 1980) and in Nov 1990 at Llano Point.

Magellanic Penguin (Spheniscus magellanicus). - One individual was recorded in the area of Point Thomas on 17 Jan 1984 (Trivelpiece et al. 1987a).

Sooty Albatross (Phoebetria fusca). - One individual was recorded over the Admiralty Bay area on 27 Feb 1979 (Jabłoński 1986).

Light-mantled Albatross (Phoebetria palpebrata). - One individual was recorded over the Admiralty Bay area on 18 Jan 1988 (Sierakowski 1991).

Blue Petrel (Halobaena caerulea). - Single individuals were observed twice over the Admiralty Bay area, over the Ecology Glacier (3 Sep 1989) and at Point Thomas (26 May 1995).

Antarctic Prion (Pachyptila vittata). - One dead individual was found at Patelnia Point on 20 March 1992.

Cattle Egret (Bubulcus ibis). - The species was recorded three times in the following Antarctic summers of: 1984/85 at Point Thomas, 1985/86 at Sphinx Hill (Trivelpiece et al. 1987a) and at Sphinx Hill on 7 Feb 1992. Each time it was a single dead individual.

Chiloé Wigeon (Anas sibilatrix). - Four males appeared on 11 Nov 1981 at Pt. Thomas after a strong storm, and stayed for 46 days on freshwater lakes (Trivelpiece et al. 1987a). 
Wilson's Phalarope (Phalaropus tricolor). - Two birds were observed on a shallow lake among moraines at Point Thomas between 27 Feb and 6 March 1995.

Chilean Skua (Stercorarius chilensis). - One bird was recorded at Demay Point on 18 Feb 1995.

\section{Discussion}

Krill, Euphausia superba, is an important element of the Antarctic food chain. It is the main component of the penguin diet, and constitutes between $86.5 \%$ (Gentoo) and up to 99\% (Adélie and Chinstrap) of their food mass (Volkman et al. 1980). In the $19^{\text {th }}$ and mid-20 th centuries, many seal and whale populations in the Southern Ocean were depleted, due to intensive exploitation of marine living resources. It was suggested that these marine mammals had competed with penguins for the same food resources, mainly krill. The decreases in their populations allowed some species of seabirds, including penguins, to increase their abundance (Trivelpiece and Volkman 1979). This might have been a reason of Pygoscelis population increase in investigated area in the 1970s (see Table 2). After years of uncontrolled harvesting, a strict protection of marine mammals took place: the International Convention for the Regulation of Whaling was ratified in 1946, and the Convention for the Conservation of Antarctic Seals - in 1972. Therefore, it was suggested that the following changes in distribution of some penguin populations reflect the recent recovery of fur seal (e.g. Trathan et al. 2012) and whale (e.g. Trivelpiece et al. 2011) populations. Moreover, the range of the pack ice surface in the winter is important for the survival of krill (Loeb et al. 1997) and can be decisive in the availability of food for penguins. The penguin food reserves have diminished due to warm winters and a reduction of the pack ice range since the early eighties (Ducklow et al. 2007). Hence, it seems that changes caused by regional warming contribute to the downward trend visible in the penguin population size of the mainly krilldependent Adélie and Chinstrap Penguins, in the Antarctic Peninsula region in the early 1990s (Hinke et al. 2007; Trivelpiece et al. 2011). On the other hand, deglaciation promotes an increase in the area of potential breeding places available to penguins and other birds.

On the western shore of Admiralty Bay, between 1977 and 1996, penguins prevailed over other birds in terms of population sizes. The absolute domination of $P$. adeliae in the area was not typical of the entire King George Island, where it was outnumbered by P. antarcticus (Jabłoński 1984b). During the study period, the number of Adélie and Chinstrap Penguins' nests in SSSI No. 8 showed a downward trend (from 23,661 in 1978 to 15,637 in 1996, and from 7,225 in 1978 to 2,308 in 1996, respectively). According to many authors, decline 
of these species was caused by drop in krill population, as a result of the warming trend and sea ice cover disappearance in the Antarctic Peninsula region (Hinke et al. 2007; Carlini et al. 2009; Korczak-Abshire 2010; Trivelpiece et al . 2011; Korczak-Abshire et al. 2012, 2013; Juáres et al. 2015). However, human disturbance also seems to be the local factor responsible for the decrease in the numbers of some species, including penguins, in the vicinity of the Arctowski Station (Chwedorzewska 2009; Chwedorzewska and Korczak 2010). The number of breeding pairs of the Gentoo Penguin diminished from 700 in 1977 to 205 in 1996 in the Point Thomas area, but the size of the colony in the Llano Point located more than $2 \mathrm{~km}$ away showed no distinct directional changes (Ciaputa and Sierakowski 1999). These trends, with small fluctuations, were continued in the following years (Chwedorzewska and Korczak 2010). Summing up, for all three Pygoscelis species, a declining trend of breeding populations in the investigated area was observed and reached $68.06 \%$ for Chinstrap, $38.04 \%$ for Gentoo and $13.13 \%$ for Adélie Penguins, which stays in accordance with the observations of other authors (e.g. Fraser and Hofmann 2003).

Decreasing population trends were also recorded for some other birds, such as Chionis albus and Sterna vittata. Sheathbills occur in the vicinity of seabird colonies and focus their activities there (Burger 1981). Therefore, it is highly probable that a decrease in abundance of Snowy Sheathbills recorded in the present study is related to the breeding population drop observed in pygoscelids. An example of positive correlation between increase of sheathbill and penguin populations was observed three decades later by González-Zevallos et al. (2013) in the northern sector of the Danco Coast, north-west of the Antarctic Peninsula.

The number of nests of Southern Giant Petrels, in one of the two breeding clusters of the Point Thomas colony located near the Arctowski Station, decreased (probably due to anthropogenic pressure), while in the second breeding cluster, $c a .1 \mathrm{~km}$ away from the station, the population remained constant. However, the number of nests in two distant colonies (Rescuers Hills and Vaureal Point) increased during the same time frame. The largest colony of Southern Giant Petrels within the South Shetlands was located on Penguin Island, opposite the entrance to King George Bay, with up to 512 nests in 1978 (Jabłoński 1980), (Fig. 1). Interestingly, at least occasionally, birds moved between King George Bay and Admiralty Bay areas. An increase in number of breeding pairs was also recorded in Daption capense.

For other breeding species, Stercorarius sp., Phalacrocorax atriceps bransfieldensis and Larus dominicanus, population sizes either remained stable or fluctuated slightly between the years. L. dominicanus populations remained relatively unchanged in some locations on King George Island even in later years (Woehler et al. 2001). In the case of Stercorarius sp., species identification is difficult due to hybridisation of the two species in the South Shetlands. Nevertheless, our observations indicate that Stercorarius sp. population was 
stable through the study period. According to other authors the South Polar Skua numbers increased at King George Island (Shuford and Spear 1988) as well as in the South Orkneys (Hemming 1984). This trend continues in the recent years (Carneiro et al. 2010). When examining Stercorarius sp. population trends in Admiralty Bay, Carneiro et al. (2010) discovered that total number of breeding skuas had increased by $293 \%$ since 1978/1979. However, there has been an overall decline (by 40\%) in Brown Skua pairs during the same time, driven primarily by a large decrease in the breeding density of their pairs in areas without penguin colonies. Populations of shags in the Antarctic Peninsula exhibit broad coherence over the region, with trends before the mid-1980s generally increasing and trends after this period decreasing. Causal factors associated with these patterns have not been identified, but changes in abundance of juvenile year-classes of fish are likely to be involved (Woehler et al. 2001).

Among 13 breeding species of birds from the Admiralty Bay, six species, Pygoscelis adeliae, P. antarcticus, Oceanites oceanicus, Fregetta tropica, Stercorarius maccormicki and S. antarcticus lonnbergi, leave the area after completing their breeding activities. A part of the population of Macronectes giganteus, Chionis albus and Larus dominicanus stay for the winter, regardless of the ice condition of the bay. Moreover, C. albus and L. dominicanus inhabit the vicinity of Antarctic Stations and for that time behave as synanthropes feeding on wastes, mostly in those periods when the bay is covered by ice. Individuals of some other breeding species, P. papua, Daption capense, Phalacrocorax atriceps bransfieldensis and Sterna vittata, stay for the winter only if the bay is partially or entirely ice-free.

There are several potential mechanisms by which vagrant individuals arrive in the Antarctic. Birds may either be drifted off-course from their normal migration routes by gales; may be ship followers during their journey or may represent the vanguard of individuals pioneering new migration routes (Korczak-Abshire et al. 2011b). For most rarely observed species, King George Island is beyond the limits of their natural range (Santos et al. 2007), and harsh conditions prevailing in Antarctica significantly reduce the likelihood of their survival (Gryz et al. 2015).

In the area of the SSSI No. 8, three species of long-distance migrants from the Northern Hemisphere were observed: the White-rumped Sandpiper - nesting in Northern Canada, wintering in Chile and Argentina south of the Tropic of Capricorn; Wilson's Phalarope - nesting in the central part of North America, wintering in Peru, Bolivia, Chile and Argentina as far as Tierra del Fuego; and the Arctic Tern - nesting from the temperate zone of the northern hemisphere to the Arctic, wintering in the Southern Hemisphere around the border of the Antarctic pack ice. Records of White Sandpiper in the study area were also noted in later years (Korczak-Abshire et al. 2011a). 
South-American species, such as the Black-necked Swan, Chiloé Wigeon, Yellow-billed Pintail and the Chilean Skua were noted after strong storms coming from a northerly direction. More observations of such a phenomenon were made by Trivelpiece et al. (1987a) and in following years by Korczak-Abshire et al. (2011b). Most non-breeding species were observed during the spring, summer or autumn and three of them, Aptenodytes forsteri, Thalassoica antarctica and Pagodroma nivea, were also observed in the winter. However, some bird species may respond to environmental changes observed in the Antarctic Peninsula, by shifting their breeding range probably due to the areas available to breed and/ or feed. For example, a single instance of King Penguin breeding attempt was registered at Stranger Point (King George Island), and the chick remained alive until 5 months old (Juáres et al. 2014, 2016).

Our long-term data represent a unique reference basis and provide valuable information about indicator species, suitable for comparison with contemporary observations of bird populations in the Antarctic Peninsula region. Any differences observed will help to understand ongoing ecological processes, especially facing the issue of rapidly occurring climate changes as well as intensive harvesting of Antarctic marine living resources. Development of recent technology in geospatial science and remote sensing provides a useful tool for direct estimation of indicator species populations, as illustrated in several publications (Trathan 2004; Schwaller et al. 2013; Southwell et al. 2013; LaRue et al. 2014; Goebel et al. 2015; Zmarz et al. 2015; Korczak-Abshire et al. 2016). Increased tourism and development of research station infrastructure, in the face of climate change, carries the threat of invasion of alien species (Lityńska et al. 2012; Augustyniuk-Kram et al. 2013; Chwedorzewska et al. 2013; Wódkiewicz et al. 2013) which can also affect the condition of the native populations of birds. For example, the presence of Salmonella sp. in the intestinal flora of the two Gentoo Penguin sampled populations were recorded within investigated area (Dimitrov et al. 2009). We hope that our data will serve to enrich the open access databases, like the Mapping Application for Penguin Populations and Projected Dynamics (MAPPPD) (www.penguinmap.com). This useful tool provides free and ready access to the population counts and modelled data, and can act as a facilitator for data transfer between scientists and Antarctic stakeholders to help inform management decisions for the continent (Humphries et al. 2017).

Acknowledgments. - Kaziemierz Sierakowski would like to thank Professor Stanisław Rakusa-Suszczewski, for making his participation in the $12^{\text {th }}, 14^{\text {th }}, 16^{\text {th }}$ and $19^{\text {th }}$ Polish Antarctic Expeditions to the Arctowski Station possible, and Professor Aleksander Wasilewski, for the scientific supervision. He would also like to thank the leaders of expeditions: Dr Piotr Presler, Paweł Madejski, Professor Maria Olech and Krzysztof Makowski for priceless help. He is particularly grateful to Professor Andrzej Tatur for his support in manuscript preparation. Authors would like to thank all reviewers, especially Dr Susan G. Trivelpiece for valuable and precious suggestions to our manuscript. The 
development of archive data has been partly supported by funding from the Polish-Norwegian Research Programme operated by the National Centre for Research and Development under the Norwegian Financial Mechanism 2009-2014 in the frame of Project Contract No 197810. The data used in the paper were collected based on Henryk Arctowski Polish Antarctic Station and are available in the Department of Antarctic Biology, Institute of Biochemistry and Biophysics, PAS.

\section{References}

Augustyniuk-Kram A., Chwedorzewska K.J., KorCZaK-Abshire M., OleCh M. and LITYŃSKA-ZAJĄC M. 2013. An analysis of fungal propagules transported to the Henryk Arctowski Station (Antarctica). Polish Polar Research 34: 269-278.

BLACK C.E. 2016. A comprehensive review of the phenology of Pygoscelis penguins. Polar Biology 39: 405-432.

BURGER A.E. 1981. Time budget, energy needs and kleptoparasitism in breeding lesser sheathbills (Chionis minor). The Condor 83: 106-112.

CArlini A.R., Coria N.R., SANTos M.M., Negrete J., JuAres M.A. and DANeri G.A. 2009. Responses of Pygoscelis adeliae and P. papua populations to environmental changes at Isla $25 \mathrm{de}$ Mayo (King George Island). Polar Biology 32: 1427-1433.

CARneiro A.P.B., Polito M.J., SANDER M. and TrivelPiece W.Z. 2010. Abundance and spatial distribution of sympatrically breeding Catharacta spp. (skuas) in Admiralty Bay, King George Island, Antarctica. Polar Biology 33: 673-682.

Chambers L.E., Altwegg R., Barbraud C., Barnard P., Beaumont L.J., Crawford R.J.M., Durant J.M., HugheS L., Keatley M.R. and Low M. 2013. Phenological changes in the Southern Hemisphere. PLOS ONE 8: e75514

CHWEDORZEWSKA K.J. 2009. Terrestrial Antarctic ecosystems at the changing world - an overview. Polish Polar Research 30: 263-273.

CHWEDORZEWSKA K.J. and KorCZAK M. 2010. Human impact upon the environment in the vicinity of Arctowski Station, King George Island, Antarctica. Polish Polar Research 31: 45-60.

Chwedorzewska K.J., KorcZaK-Abshire M., Olech M., LityńsKa-Zając M. and AugustyNIUK-KRAM A. 2013. Alien invertebrates transported accidentally to the Polish Antarctic Station in cargo and on fresh foods. Polish Polar Research 34: 55-66.

CiAPUTA P. and SieraKOWSKI K. 1999. Long-term population changes of Adélie, chinstrap and gentoo penguins in the regions of SSSI No. 8 and SSSI No. 34, King George Island, Antarctica. Polish Polar Research 20: 355-365.

CROXAll J.P. and KIRKWOOD E.D. 1979. The distribution of penguins on the Antarctic Peninsula and Islands of the Scotia Sea. Abundance and spatial distribution of sympatrically breeding Catharacta spp. (skuas) in Admiralty Bay, King George Island, Antarctica, Cambridge: 186 pp.

Del Hoyo J., ElliotT A. and Sargatal J. 1991-1999. Handbook of the Birds of the World. Vol. 1 and 3. Lynx Edicions, Barcelona: 696 pp.

Dimitrov K., Metcheva R. and Kenarova A. 2009. Salmonella presence - an indicator of direct and indirect human impact on Gentoo in Antarctica. Biotechnology \& Biotechnological Equipment 23: 246-249.

DucKlow H., BAKer K., Martinson D.G., Quetin L.B., Ross R.M., SMith R.C., STAMmeRJOHN S.E., VERNET M. and FRASER W.R. 2007. Marine pelagic ecosystems: the West Antarctic Peninsula. Philosophical Transactions of the Royal Society, B 362: 67-94. 
FRASER W.R. and HOFMANN E. 2003. A predator's perspective on causal links between climate change, physical forcing and ecosystem response. Marine Ecology Progress Series 265: 1-15.

GAIN L. 1914. Oiseaux Antarctiques. Deuxieme Expedition Antarctique Francaise 1908-1910, Paris: $200 \mathrm{pp}$.

Gilg O., Kovacs K.M., Aars J., Fort J., Gauthier G., Grémillet D., Ims R.A., Meltofte H., Moreau J., Post E., Schmidt N.M., YAnniC G. and Bollache L. 2012. Climate change and the ecology and evolution of Arctic vertebrates. Annals of the New York Academy of Sciences 1249: 166-190.

Goebel M.E., Perryman W.L., Hinke J.T., Krause D.J., Hann N.A., Gardner S. and LeRoi D.J. 2015. A small unmanned aerial system for estimating abundance and size of Antarctic predators. Polar Biology 38: 619-630.

González-Zevallos D., Santos M., Rombolá E., JuÁres M. and Coria N. 2013. Abundance and breeding distribution of seabirds in the northern part of the Danco Coast, Antarctic Peninsula. Polar Research 32: 11133.

Gryz P., KorCZAK-Abshire M. and GerléE A. 2015. First record of the Austral Negrito (Aves: Passeriformes) from the South Shetlands, Antarctica. Polish Polar Research 36: 297-304.

HAMMER Ø., HARPER D.A.T. and RYAN P.D. 2001. PAST: Paleontological statistics software package for education and data analysis. Palaeontologia Electronica 4: 9 pp.

Hemmings A.D. 1984. Aspects of the breeding biology of McCormick's Skua Catharacta maccormicki at Signy Island, South Orkney Islands. British Antarctic Survey Bulletin 65: 65-79.

Hindell M.A., BradShaW C.J.A., BROOK B.W., FordHAM D.A., KERRY K., Hull C. and MCMAHON C.R. 2012. Long-term breeding phenology shift in royal penguins. Ecology and Evolution 2: $1563-1571$.

Hinke J.T., Salwicka K., Trivelpiece S.G., Watters G.M. and TrivelPiece W.Z. 2007. Divergent responses of Pygoscelis penguins reveal a common environmental driver. Oecologia 153: $845-855$.

Humphries G.R.W., Naveen R., Schwaller M., Che-Castaldo C., McDowall P., Schrimpf M. AND LYNCH H.J. 2017. Mapping Application for Penguin Populations and Projected Dynamics (MAPPPD): data and tools for dynamic management and decision support. Polar Record 53: $160-166$.

JABŁOŃSKI B. 1980. Distribution and numbers of birds and pinnipeds on Penguin Island (South Shetland Islands) in January 1979. Polish Polar Research 1: 109-116.

JABŁOŃSKI B. 1984a. Distribution, number and breeding preferences of penguins in the region of the Admiralty Bay (King George Island, South Shetland Islands) in the season 1979/1980. Polish Polar Research 5: 5-16.

JABŁOŃSKI B. 1984b. Distribution and numbers of penguins in the region of King George Island (South Shetland Islands) in the breeding season 1980/1981. Polish Polar Research 5: $17-30$.

JABŁOŃSKI B. 1986. Distribution, abundance and biomass of a summer community of birds in the region of the Admiralty Bay (King George Island, South Shetland Islands, Antarctica) in 1978/1979. Polish Polar Research 7: 217-260.

JABŁOŃSKI B. 1987. Diurnal pattern of changes in the number of penguins on land and the estimation of their abundance (Admiralty Bay, King George Island, South Shetland Islands). Acta Zoologica Cracoviensia 30: 97-118.

JABŁOŃSKI B. 1995. Distribution, abundance and biology of the Antarctic Tern Sterna vittata Gmelin 1789, on King George Island (South Shetland Islands). Acta Zoologica Cracoviensia 38: 399-460. 
Juáres M.A., Negrete J., Mennucci J.A., Perchivale P.J., Santos M., Moreira M.E. and CoRIA N.R. 2014. Further evidence of king penguins' breeding range extension at South Shetland Islands? Antarctic Science 26: 261-262.

Juáres M.A., Santos M., Negrete J., Mennucci J.A., Perchivale P.J., Casaux R. and CoRIA N.R. 2015. Adélie penguin population changes at Stranger Point: 19 years of monitoring. Antarctic Science 27: 455-461.

JuÁres M.A., FERrer F., CORIA N.R. and SANTOS M.M. 2016. Breeding events of king penguin at the South Shetland Islands: Has it come to stay? Polar Biology 27: 455-461.

KeJNA M. 1992. Próba wydzielenia termicznych pór roku na stacji H. Arctowskiego, Szetlandy Południowe w latach 1978-1989. Problemy Klimatologii Polarnej 34: 21-29.

KeJNA M. 1999. Air Temperature on King George Island (South Shetland Islands, Antarctica). Polish Polar Research 20: 183-201.

Kejna M., ARAŹny A. and Sobota I. 2013. The climatic change on King George Island (South Shetland Islands, Antarctica) in the years of 1948-2011. Polish Polar Research 2: 213-235.

KORCZAK-ABSHIRE M. 2010. Climate change influences on Antarctic bird populations. Papers on Global Change IGBP 17: 43-53.

KORCZAK-ABSHIRE M., ANGIEL P.J. and WIERZBICKI G. 2011a. Records of white-rumped sandpiper (Calidris fuscicollis) on the South Shetland Islands. Polar Record 47: 262-267.

KorCZAK-ABSHIRE M., LEES A.C. and JoJCZYK A. 2011b First documented record of Barn Swallow Hirundo rustica in the Antarctic. Polish Polar Research 32: 355-360.

KorcZAK-Abshire M., ChwedorzewsKa K.J., WĄsowicz P. and BednAREK P.T. 2012. Genetic structure of declining chinstrap penguin (Pygoscelis antarcticus) populations from South Shetland Islands (Antarctica). Polar Biology 35: 1681-1689.

KorCZAK-Abshire M., WęGRZYN M., ANGIEL P.J. and LisowsKa M. 2013. Pygoscelid penguin breeding distribution and population trends at Lions Rump rookery (South Shetland Islands). Polish Polar Research 34: 87-99.

KorczaK-Abshire M., Kidawa A., Zmarz A., Storvold R., Karlsen S.R., Rodzewicz M., CHWEDORZEWSKA K. and ZNÓJ A. 2016. Preliminary study on nesting Adélie penguins disturbance by unmanned aerial vehicles. CCAMLR Science 23: 1-16.

KÖRNER C. and BASLER D. 2010. Phenology under global warming. Science 327: 1461-1462.

KRUSZEWSKI G. 2002. Zlodzenie Zatoki Admiralicji-przebieg i uwarunkowania. Akademia Morska, Gdynia: 123 pp.

LaRue M.A., Lynch H.J., LyVer P.O.B., BARTON K., Ainley D.G., Pollard A., Fraser W.R. and BALLARD G. 2014. A method for estimating colony sizes of Adélie penguins using remote sensing imagery. Polar Biology 37: 507-517.

LESIŃSKI G. 1993. Monitoring of birds and pinnipedians on King George Island (South Shetland Islands) in 1989/1990. Polish Polar Research 14: 75-89.

LityŃska-Zając M., ChWedorzewska K.J., Olech M., KorCZAK-Abshire M. and AugustyNIUK-KRAM A. 2012. Diaspores and phyto-remains accidentally transported to the Antarctic Station during three expeditions. Biodiversity and Conservation 21: 3411-3421.

Loeb V., Holm-Hansen O., Hewitt R., Fraser W., Trivelpiece W. and Trivelpiece S. 1997. Effects of sea-ice extent and krill or salp dominance on the Antarctic food web. Nature 387: 897-900.

Lynch H.J., NAVEen R., Trathan P.N. and Fagan W.F. 2012. Spatially integrated assessment reveals widespread changes in penguin populations on the Antarctic Peninsula. Ecology 93: $1367-1377$.

Menzel A., Sparks T.H., Estrella N., Koch E., Aasa A., Ahas R., Alm-KÜBler K., BissolLI P., BRASLAVSKA O. and BRIEDE A. 2006. European phenological response to climate change matches the warming pattern. Global Change Biology 12: 1969-1976. 
MYRCHA A. 1993. Birds. In: S. Rakusa-Suszczewski (ed.), The maritime Antarctic coastal ecosystem of Admiralty Bay. Department of Antarctic Biology, Polish Academy of Sciences, Warszawa: 129-141.

PRESLER P. 1980. Phenological and physiographical observations carried out during the first wintering at the Arctowski Station in 1977. Polskie Archiwum Hydrobiologiczne 27: 245-252.

Santos M.M., Montalti D., Juares M., Coria N.R. and ARChuby D. 2007. First record of the austral thrush (Turdus falcklandii) from the South Shetland Islands, Antarctica. Notornis 54: 231-232.

Schwaller M.R., Southwell C.J. and EMmerson L.M. 2013. Continental-scale mapping of Adélie penguin colonies from Landsat imagery. Remote Sensing of Environment 139: 353-364.

SHUFORD W.D. and SPEAR L.B. 1988. Surveys of breeding penguins and other seabirds in the South Shetland Islands, Antarctica, January - February 1987. National Oceanic and Atmospheric Administration. Technical Memorandum NMFS-F/NEC-59, Woods Hole, Massachusetts: $33 \mathrm{pp}$.

Sibley Ch.G. and Monroe JR B.L. 1990. Distribution and Taxonomy of Birds of the World. Yale University Press, New Haven \& London: 1111 pp.

SIERAKOWSKI K. 1991. Birds and mammals in the region of SSSI No. 8 in the season 1988/89 (South Shetlands, King George Island, Admiralty Bay). Polish Polar Research 12: 25-54.

Southwell C., MCKinlay J., LOW M., Wilson D., NEWBery K., LIESER J.L. and EMMERSON L. 2013. New methods and technologies for regional-scale abundance estimation of land-breeding marine animals: application to Adélie penguin populations in East Antarctica. Polar Biology 36: $843-856$.

SYDEMAN W.J. and BogARD S.J. 2009. Marine ecosystems, climate and phenology: introduction. Marine Ecology Progress Series 393: 185-188.

TRATHAN P.N. 2004. Image analysis of color aerial photography to estimate penguin population size. Wildlife Society Bulletin 32: 332-343.

TRATHAN P.N., RATCLIFFE N. and MASDEN E.A., 2012. Ecological drivers of change at South Georgia: the krill surplus, or climate variability. Ecography 35: 983-993.

TRIVELPIECE W. and VOLKMAN N.J. 1979. Nest-site competitions between Adélie and Chinstrap penguins: an ecological interpretation. The Auk 96: 675-681.

TrivelPiece W., Butler R.G. and VolKMAn N.J. 1980. Feeding territories of Brown Skuas (Stercorarius lonnbergi). The Auk 97: 669-676.

TRIVELPIECE W. and VolKMAN N.J. 1982. Feeding strategies of sympatric South Polar Skuas Stercorarius maccormicki and Brown Skuas C. lonnbergi. Ibis 124: 50-54.

Trivelpiece S.G., Geupel G.R., KJelmyr J., Myrcha A., SicińsKi J., Trivelpiece W.Z. and VOLKMAN N.J. 1987a. Rare bird sightings from Admiralty Bay, King George Island, South Shetland Islands, Antarctica, 1976-1987. Cormorant 15: 59-66.

TRIVELPIECE W.Z., TRIVELPIECE S.G. and VOLKMAN N.J. 1987b. Ecological segregation of Adélie, Gentoo and Chinstrap Penguins at King George Island, Antarctica. Ecology 68: 351-361.

Trivelpiece W.Z., TrivelPIECE S.G., GeuPEl G.R., KJelmyR J. and VolKMAN N.J. 1990. Adélie and chinstrap penguins: their potential use as monitors of the Southern Ocean Marine Ecosystems. In: Kerry K.R. and G. Hempel (eds), Antarcic Ecosystems. Ecological change and conservation. Springer-Verlag Berlin Heidelberg: 191-202.

Trivelpiece W.Z., Hinke J.T., Miller A.K., Reiss C.S., TrivelPiece S.G. and WATters G.M. 2011. Variability in krill biomass links harvesting and climate warming to penguin population changes in Antarctica. Proceedings of the National Academy of Sciences 108: 7625-7628.

Volkman N.J., PRESLER P. and TrivelPIECE W.Z. 1980. Diets of pygoscelid penguins at King George Island, Antarctica. The Condor 82: 373-378. 
WASILEWSKI A. 1986. Ecological aspects of the breeding cycle in the Wilson's storm petrel, Oceanites oceanicus (Kuhl) at King George Island (South Shetland Islands, Antarctica). Polish Polar Research 7: 173-216.

Woehler E.J., CoOper J., Croxall J.P., Fraser W.R., Kooyman G.L., Miller G.D., Nel D.C., Patterson D.L., Peter H.U., Ribic C.A., SAlwicka K., Trivelpiece W.Z. and WeimerSKIRCH H. 2001. A statistical assessment of the status and trends of Antarctic and sub Antarctic seabirds. Report on SCAR BBS Workshop on Southern Ocean seabirds populations: 1-45.

WódKiewicz M., Galera H., GieŁwanowska I., ChwedorzewsKa K.J. and Olech M. 2013. Diaspores of the introduced species Poa аппиа L. in soil samples from King George Island (South Shetlands, Antarctic). Arctic, Antarctic and Alpine Research 45: 415-419.

ZMARZ A., KorCZAK-AbShire, M., STORVOld R., RODZEWICZ M. and KĘDZIERSKA I. 2015. Indicator species population monitoring in Antarctica with UAV. The International Archives of the Photogrammetry, Remote Sensing and Spatial Information Sciences XL-1/W4: 189-193.

Received 4 September 2015

Accepted 3 March 2017 